(C) 2018. This manuscript version is made available under the CC-BY-NC-ND 4.0 license http://creativecommons.org/licenses/by-nc-nd/4.0/

\title{
Marine biodiversity and ecosystem function relationships: The potential for practical monitoring applications
}

James Asa Strong a, * Eider Andonegi ${ }^{\mathrm{b}}$, Kemal Can Bizsel ${ }^{\mathrm{c}}$, Roberto Danovaro d, Mike Elliott ${ }^{a}$, Anita Franco ${ }^{a}$, Esther Garces ${ }^{e}$, Sally Little ${ }^{a}$, Krysia Mazik a, Snejana Moncheva ${ }^{f}$, Nadia Papadopoulou 9, Joana Patrício ${ }^{h}$, Ana M. Queir os i, Chris Smith g, Kremena Stefanova ${ }^{\dagger}$, Oihana Solaun ${ }^{b}$

a The Institute of Estuarine and Coastal Studies, University of Hull, Hull HU6 7RX, UK b AZTI - Tecnalia, Astondo Bidea, Edificio 609, Parque Tecnol ogico de Bizkaia, 48160 Elexalde Derio, Vizcaya, Spain

c Institute of Marine Sciences and Technology Baku, Blvd. No 100, P.K. 478 InciraltiIzmir, Turkey

d CONISMA, Polytechnic University of Marche, Piazza Roma, 22, 60121 Ancona, Italy e Institut de Ci encies del Mar, CSIC, Spain, Passeig Marítim de la Barceloneta, 37-49, E-08003 Barcelona, Spain

f Institute of Oceanology-BAS, First May Street 40, P.O.Box 152, Varna 9000, Bulgaria g Hellenic Centre of Marine Research, Athens Sounio Ave. P.C., 19013 Anavyssos Attiki, Greece

h European Commission, Joint Research Centre, E. Fermi 2749, 21027 Ispra (VA), Italy

i Plymouth Marine Laboratory, Prospect Place, The Hoe, Plymouth PL1 3DH, UK

Corresponding author: j.strong@hull.ac.uk (J.A. Strong)

Abstract

There is an increasing demand for environmental assessments of the marine environment to include ecosystem function. However, existing schemes are predominantly based on taxonomic (i.e. structural) measures of biodiversity. Biodiversity and Ecosystem Function (BEF) relationships are suggested to provide a mechanism for converting taxonomic information into surrogates of ecosystem function. This review assesses the evidence for marine BEF relationships and their potential to be used in 
practical monitoring applications (i.e. operationalized).

Five key requirements were identified for the practical application of BEF relationships: (1) a complete understanding of strength, direction and prevalence of marine BEF relationships, (2) an understanding of which biological components are influential within specific BEF relationships, (3) the biodiversity of the selected biological components can be measured easily, (4) the ecological mechanisms that are the most important for generating marine BEF relationships, i.e. identity effects or complementarity, are known and (5) the proportion of the overall functional variance is explained by biodiversity, and hence BEF relationships, has been established.

Numerous positive and some negative BEF relationships were found within the literature, although many reproduced poorly the natural species richness, trophic structures or multiple functions of real ecosystems (requirement 1). Null relationships were also reported. The consistency of the positive and negative relationships was often low that compromised the ability to generalize BEF relationships and confident application of BEF within marine monitoring. Equally, some biological components and functions have received little or no investigation.

Expert judgement was used to attribute biological components using spatial extent, presence and functional rate criteria (requirement 2). This approach highlighted the main biological components contributing the most to specific ecosystem functions, and that many of the particularly influential components were found to have received the least amount of research attention.

The need for biodiversity to be measureable (requirement 3 ) is possible for most biological components although difficult within the functionally important microbes. Identity effects underpinned most marine BEF relationships (requirement 4). As such, processes that translated structural biodiversity measures into functional diversity were found to generate better BEF relationships.

Keywords:

biodiversity and ecosystem function; relationships; marine; practical applications; operationalization; monitoring 


\section{Introduction}

The physical, chemical and biological processes that transform and translocate energy or materials in an ecosystem are termed ecosystem functions (Naeem, 1998; Paterson et al., 2012). Ecosystem functioning generally describes the combined effects of individual functions, with the overall rate of functioning being governed by the interplay of abiotic (physical and chemical) and/or biotic factors (Reiss et al., 2009). Of these biotic factors, the influence of biodiversity is widely cited as being influential and is referred to as the 'Biodiversity and Ecosystem Function' relationship (BEF). Furthermore, these ecosystem functions represent a significant component of ecosystem health (Tett et al., 2013) and provide ecosystem services that benefit society (Paterson et al., 2012).

The need to ensure the sustainable functioning of aquatic ecosystems is acknowledged by many marine policy obligations, either explicitly (e.g. the European Marine Strategy Framework Directive, MSFD, 2008/56/EU), or indirectly by addressing structural aspects which can be related to functioning (e.g. Water Framework Directive, 2000/60/EC, and Habitats Directive, 1992/43/EEC). The MSFD aims to achieve Good Environmental Status (GEnS) of European seas by 2020 . The MSFD definition of GEnS includes the requirement that 'the structure, functions and processes of the constituent marine ecosystems allow those ecosystems to function fully'. The GEnS assessment can be interpreted as requiring (1) functioning to be considered at all levels of biological organization (i.e. cell, individual, population, community and ecosystem) and (2) the potential to relate these functions to GEnS indicators and overall ecosystem health (Tett et al., 2013). Consequently, this review aims to assessing the evidence for BEF relationships and their potential to be used in the monitoring of ecosystem functions.

Structurally-based biodiversity assessments, such as species richness and abundance (Gray and Elliott, 2009), are extensively used to monitor components of the marine ecosystem (Birk et al., 2012). These structural indicators are routinely used because they are well established, cost-effective and provide structural surrogate indicators of ecosystem condition and functional state (Gray and Elliott, 2009). However, using BEF relationships in practical monitoring applications ('operationalizing' BEF) provides a more direct and tangible link by which biological diversity information can be translated into surrogates of ecosystem functionality that ultimately help fulfil monitoring obligations and policy goals. Although direct measurements of specific ecosystem functions are often more straight-forward and cost- 
effective, the use of biodiversity information and BEF relationships has the following benefits: (1) one biological dataset can provide surrogates of multiple ecosystem functions; (2) combines the analysis of structural and functional status; (3) predictions of ecosystem function can be generated, based on known sensitivity of individual species, within realistic patterns of biodiversity loss; and (4) functional evaluations, based on biodiversity, incorporate the biological apparatus of functional delivery within the same assessment.

This review aims to explore the prevalence and nature of marine BEF relationships and the potential of these relationships to be used in operational monitoring of marine environmental health. The key objectives are to (1) identify what information is required for the consistent and confident application of BEF relationships within ecosystem functioning monitoring; (2) review the evidence for BEF relationships including details about strength, consistency, direction and the mechanism of delivery (i.e. complementarity and identity effects); (3) identify the relevant biological components (i.e. broad biological groupings, based on either taxonomic or ecological similarity, could include for example microbes, benthic invertebrates, phytoplankton, and fish) for specific ecosystem functions; (4) provide a framework for the incorporation of BEF relationships within marine monitoring; and (5) assess the limitations and future work required to fully implement BEF relationships within functional monitoring. Hence we give: (1) the key requirements for the practical application; (2) a review of the BEF evidence in relation to these requirements and (3) an overall assessment of the potential of BEF relationships to be used in practical applications of ecosystem monitoring and a framework by which this could be achieved.

\subsection{Biodiversity and ecosystem functioning relationships}

BEF research has recently proliferated in response to scientific and public awareness of the widespread and unprecedented biodiversity turnover (13 diversity scale) and loss in many biological components (Pimm et al., 1995; Bulling et al., 2010; Dornelas et al., 2014; Pandolfi and Lovelock, 2014) induced by human activity and climate change (Loreau et al., 2001; Covich et al., 2004). Such changes have potential implications for the provision of ecosystem services and societal benefits (Chapin et al., 1997; Covich et al., 2004; Solan et al., 2004; Worm et al., 2006; Atkins et al., 2011; Cardinale et al., 2012; Hooper et al., 2012; UK National Ecosystem Assessment, 2014). BEF research is increasingly centred on whether altered species diversity affects functions (Loreau et al., 2001; Covich et al., 2004).

The underlying BEF theory postulates that changes in biodiversity will result in altered 
ecosystem functions, i.e. that higher and more efficient functioning rates come from highly diverse areas. This is presumed to be because diverse communities are more likely to contain a greater range of functional traits and environmental sensitivities (Chapin et al., 1997). High diversity therefore entails opportunities for more efficient resource use as well as providing stability to ecosystem functions in variable environments and in the face of disturbance (Chapin et al., 1997). Alternatively, systems with species-poor communities are theoretically likely to be functionally poorer, less resistant (capacity to resist change) and resilient (capacity to recover from change) to disturbance than systems with species-rich communities (Covich et al., 2004; Stachowicz et al., 2007).

Biodiversity and ecosystem function relationships, if present, can take many forms (Fig. 1). These can be positive or negative linear (proportional gain or loss) or exponential (high and low redundancy models) relationships (Naeem and Wright, 2003). Positive, linear BEF relationships suggest that additional units of biodiversity have an equal and additive contribution to an ecosystem function (Naeem and Wright, 2003). This would also be indicative of situations where complementarity (transgressive over-yielding) was occurring, i.e. individual species perform better in diverse communities when compared to monoculture due to facilitation and niche partitioning in shared resource use. Logarithmic relationships are likely when several biodiversity units are capable of providing the same function, and therefore the same change in ecosystem function. The species range beyond the asymptote are often considered to be redundant (Naeem and Wright, 2003). Complementarity provides what might be considered the truest form of a BEF relationship. However, in situations where particular species have a disproportionate functional role, they can also generate positive BEF relationships and are termed identity effects (this form of non-transgressive over-yielding can also be called sampling or selection effects). Where identity effects are prevalent, stepped or riveted relationships might be apparent. A brief summary of BEF concepts and mechanisms is only given here to allow a better understanding of the results presented in this paper; further detailed information can be found in Scherer-Lorenzen (2005) and Reiss et al. (2009). 

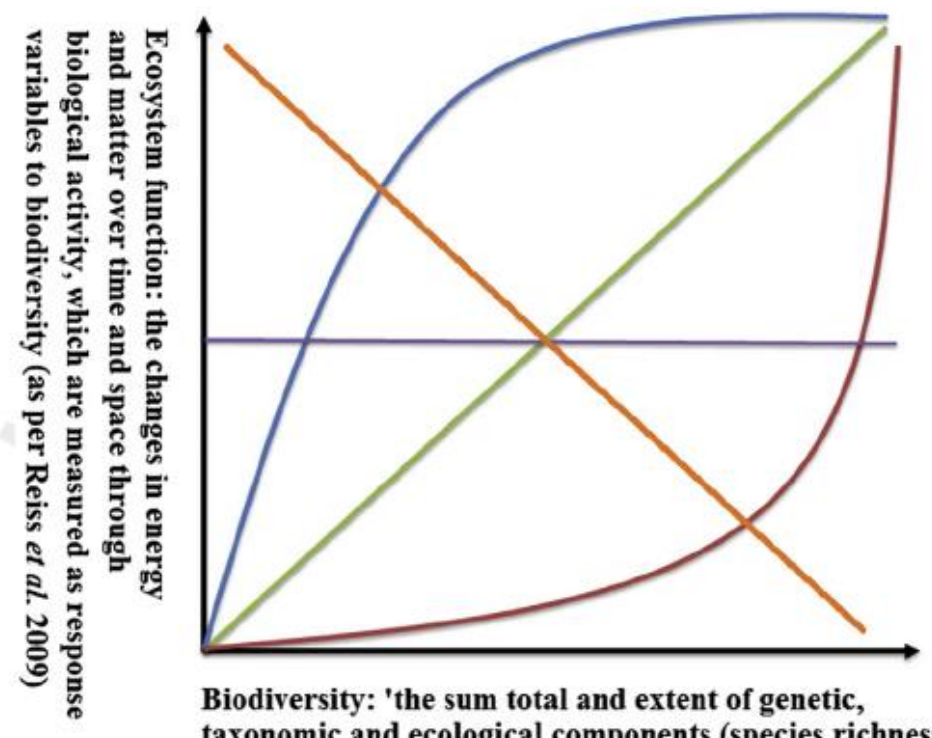

Proportional loss - each

species contributed

equally to function

High redundancy model

Low redundancy

No BEF relationship

Biodiversity: 'the sum total and extent of genetic, taxonomic and ecological components (species richness and composition) over several spatial and temporal scales' (modified from Naeem et al. (2002))

Fig. 1. Potential ‘Biodiversity and Ecosystem Function’ relationships.

\section{Practical application of BEF relationships within GEnS monitoring and management}

Despite equivocal evidence, there is a general consensus that marine biodiversity and ecosystem function relationships do exist, and positive and negative effects of biodiversity have been observed in several marine ecosystem functions (Worm et al., 2006; Stachowicz et al., 2007; Cardinale et al., 2012; Gamfeldt et al., 2014). Although the overall form of many BEF relationships has been documented (Stachowicz et al., 2007; Naeem et al., 2009; Cardinale et al., 2012; Gamfeldt et al., 2014) this alone does not provide sufficient information to immediately use these relationships for practical applications (operationalize). Five key issues, as considered below, aim to define whether BEF relationships can form an integrated component in consistent, pragmatic and informative marine monitoring. This requires us to investigate the following 'operational requirements': (1) the existence of BEF relationships, (2) which biological components contribute to which ecosystem functions and therefore involved in specific BEF relationships, (3) whether the biodiversity and function of the selected biological components be measured easily, (4) detail which mechanisms generate BEF relationships, i.e. identity effects or complementarity, and (5) establish what proportion of the overall variance of a given function is explained by biodiversity, and hence 
by BEF relationships. These operational requirements are critical for both the director modelled calculation of BEF in monitoring.

\subsection{Operational requirement 1 : do BEF relationships exist in marine ecosystems?}

Although there is broad acceptance of marine BEF relationships, there is also recognition of their variability and context dependency (Bulling et al., 2010; Cardinale et al., 2012). Practical monitoring applications incorporating BEF however requires the existence of a clear, consistent and unambiguous relationship between habitats, biological components and ecosystem functions. Furthermore, simply knowing the presence and direction of a BEF relationship is not sufficient for its operational use. The shape of the functional response between a biodiversity indicator and a specific ecosystem function (linear, logarithmic, exponential, power, etc.) also needs to be determined so that predictions can be made across the full range of biodiversity. Although different types of BEF relationships have been demonstrated in the literature, especially positive relationships, there is no reason why negative BEF relationships cannot be used in monitoring methodologies. However, the incorporation of positive BEF relationships within a practical ecosystem monitoring application is particularly desirable as improvements in the system structure (biodiversity) would also lead to an improvement in its functioning, thereby generating synergistic enhancements in both conservation and ecological objectives.

High level and holistic measures of ecosystem functioning that account for multifunctionality are rare, with the majority of the literature focussing on the relevance of biodiversity in the context of specific functions (Mouillot et al., 2011). Accordingly, evidence for $\mathrm{BEF}$ relationships in marine temperate systems is grouped under five broad processes (groupings of ecosystem functions) of (1) biomass production, (2) organic matter transformation, (3) ecosystem metabolism, (4) nutrient cycling and (5) physical engineering (Fig. 2). This grouping generally agrees with that used by Giller et al. (2004), representing key functions that control and distribute resources in marine ecosystems (nutrients, energy, physical space/habitat), through interactions such as production, consumption and transformation. Within these five processes, the reviewed evidence is collated by discrete biological components including microbes, phytoplankton, zooplankton, macroalgae, angiosperms, benthic invertebrates, fish and cephalopods, seabirds, reptiles and marine mammals. 


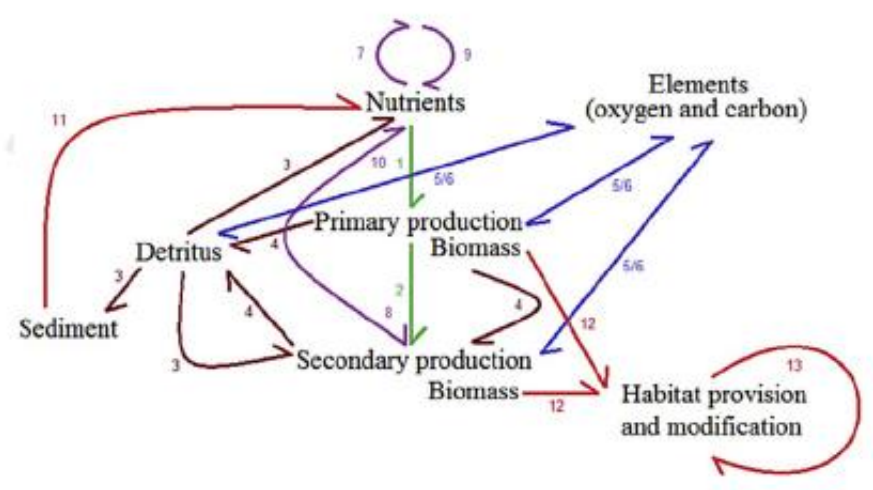

Biomass production

1 Primary production

2 Secondary production

Organic matter transformation

3 Organic matter decomposition and removal

4 Import/export or organic matter

Ecosystem metabolism

5 Oxygen consumption and carbon mineralization

6 Oxygen production

Nutrient cycling

7 Denitrification

8 Nitrification

9 Nitrogen fixation

10 Exchange of limiting nutrients

Physical engincering

11 Bioturbation

12 Reef building

13 Water baffling, particle flux and sedimentation

Fig. 2. Relationships between ecosystem functions used within the review.

\subsubsection{Ecosystem process: biomass production}

The rate at which biomass is generated, both by autotrophic and heterotrophic organisms, is a key process supporting the functioning of a viable ecosystem. Primary production, via photosynthesis and chemosynthesis, provides the biomass to support secondary production, thereby allowing energy and nutrient transfer across trophic levels (Fig. 2). Secondary production is widely accepted as a critical ecosystem process and is regularly used as a functional metric. Phytoplankton, chemosynthetic microbes, macroalgae and angiosperms are the main primary producers in temperate marine ecosystems (Table 1), supporting heterotrophic microbes, zooplankton, nekton and benthic invertebrates via trophic links. In addition, both primary and secondary production generate by-products that support other ecosystem functions (e.g. ecosystem metabolism, nutrient cycling). 
Table 1. Ecosystem functions associated with differing marine biological components (functions modified from Giller $e$ al. 2004). Expert judgement was used to allocate low (1) to high (5) values for spatial extent/prevalence (first value), presence, i.e. standing

biomass/abundance (second value) and functional rate (third value). Values have been multiplied together to generate a summary value of the potential functional output at the regional scale.

\begin{tabular}{|c|c|c|c|c|c|c|c|c|}
\hline $\begin{array}{l}\text { Functional } \\
\text { category }\end{array}$ & Ecosystem function & Microbes & $\begin{array}{l}\text { Phytoplankto } \\
\mathrm{n}\end{array}$ & Zooplankton & Macroalgae & Angiosperms & $\begin{array}{l}\text { Benthic } \\
\text { invertebrates }\end{array}$ & $\begin{array}{l}\text { Higher } \\
\text { trophic } \\
\text { levels }\end{array}$ \\
\hline \multirow{2}{*}{$\begin{array}{l}\text { Biomass } \\
\text { production }\end{array}$} & Primary productivity & $\begin{array}{l}5 * 1.5 * 3=22 . \\
5\end{array}$ & $4 * 2.5 * 5=50$ & & $2 * 5 * 3=30$ & $1 * 5 * 3=15$ & & \\
\hline & Secondary productivity & $\begin{array}{l}5 * 2.5 * 3=37 . \\
5\end{array}$ & & $4 * 3 * 4=48$ & & & $3 * 3 * 3=27$ & $4 * 2 * 1=8$ \\
\hline \multirow{2}{*}{$\begin{array}{l}\text { Organic } \\
\text { matter } \\
\text { transformati } \\
\text { on }\end{array}$} & $\begin{array}{l}\text { Organic matter } \\
\text { decomposition and } \\
\text { removal }\end{array}$ & $5 * 2.5 * 4=50$ & & & & & $3 * 3 * 3=27$ & $4 * 2 * 1=8$ \\
\hline & $\begin{array}{l}\text { Import/export of organic } \\
\text { matter }\end{array}$ & & $4 * 2.5 * 5=50$ & $4 * 3 * 4=48$ & $2 * 5 * 3=30$ & $1 * 5 * 3=15$ & $3 * 3 * 3=27$ & $4 * 2 * 1=8$ \\
\hline \multirow{3}{*}{$\begin{array}{l}\text { Ecosystem } \\
\text { metabolism }\end{array}$} & Carbon mineralisation & $5 * 2.5 * 4=50$ & & $4 * 3 * 4=48$ & & & $3 * 3 * 3=27$ & $4 * 2 * 1=8$ \\
\hline & Oxygen consumption & $5 * 2.5 * 4=50$ & & $4 * 3 * 4=48$ & & & $3 * 3 * 3=27$ & $4 * 2 * 1=8$ \\
\hline & Oxygen production & & $4 * 2.5 * 5=50$ & & $2 * 5 * 3=30$ & $1 * 5 * 3=15$ & & \\
\hline \multirow{4}{*}{$\begin{array}{l}\text { Nutrient } \\
\text { cycling }\end{array}$} & Denitrification & $2 * 2.5 * 4=20$ & & & & & & \\
\hline & Nitrification & $5 * 2.5 * 4=50$ & & & & & & \\
\hline & Nitrogen fixation & $4 * 2.5 * 4=40$ & & & & & & \\
\hline & $\begin{array}{l}\text { Exchange of limiting } \\
\text { nutrients }\end{array}$ & $5 * 2.5 * 4=50$ & $4 * 2.5 * 5=50$ & $4 * 3 * 4=48$ & $2 * 5 * 3=30$ & $1 * 5 * 3=15$ & $3 * 3 * 3=27$ & $4 * 2 * 1=8$ \\
\hline \multirow[b]{3}{*}{$\begin{array}{l}\text { Physical } \\
\text { engineering }\end{array}$} & Bioturbation & & & & & & $3 * 3 * 3=27$ & \\
\hline & Habitat provision & & & & $2 * 5 * 3=30$ & $2 * 5 * 3=30$ & $3 * 3 * 3=27$ & \\
\hline & $\begin{array}{l}\text { Water velocity and } \\
\text { particle flux } \\
\text { modification }\end{array}$ & & & & $2 * 5 * 3=30$ & $2 * 5 * 3=30$ & $3 * 3 * 3=27$ & \\
\hline
\end{tabular}

${ }^{1}$ Fish, cephalopods, seabirds, reptiles and marine mammals. 


\subsubsection{Ecosystem function: primary production.}

The primary route of carbon fixation is photosynthesis. Phytoplankton photosynthetically fixes up to 50,000 $\mathrm{Tg} \mathrm{C} \mathrm{yr}^{\sim 1}$, contributing to nearly half of global primary production (Longhurst et al., 1995) (on average $140 \mathrm{~g} \mathrm{C} \mathrm{m}^{2} \mathrm{yr}^{\sim 1}$ Falkowski et al., 1998). Although oceanic autotrophs account for approximately $46 \%$ of the biospheric net primary production, they only account for about $0.2 \%$ of the global primary producer biomass (Field et al., 1998), and so standing biomass does not reflect production (Cebrian, 2002).

Suzuki (1997) suggests that the total global area of marine macroalgae and angiosperms is approx. 600,000 km² producing approx. $0.46 \mathrm{Tg} \mathrm{C} \mathrm{yr}^{\sim 1}$. Muraoka (2004) suggests that this is equal to $23 \%$ of the total of oceanic carbon dioxide uptake estimation by Siegenthaler and Sarmiento (1993). Microbes can also synthesize inorganic carbon using reduced chemical compounds as energy sources, contributing to about $52 \%$ of carbon fixation globally via microbial nitrification processes (estimated addition of organic matter approx. $7700 \mathrm{Tg} \mathrm{C} \mathrm{y}^{1}$; Middelburg, 2011). This suggests that chemosynthetic processes can be quantitatively more important than previously thought (Molari et al., 2013). Despite this, there have been no investigations of microbial BEF associated with chemosynthetic primary production.

\subsubsection{Ocean autotrophs.}

Many BEF-related studies have identified positive relationships between phytoplankton species richness (taken as an indicator of biodiversity) and primary production (Balvanera et al., 2006; Cardinale et al., 2006, 2007; Hector et al., 2007; Ptacnik et al., 2008; Goebel et al., 2014). Experimental studies have revealed positive, asymptotically saturating relationships between ecosystem-wide phytoplankton diversity and productivity (Goebel et al., 2014). Within the positive BEF relationships identified, both identity effects and complementarity are present and produce positive diversity_-productivity relationships (Loreau and Hector, 2001; Cardinale et al., 2006).

\subsubsection{Macroalgae.}

Both negative (Kraufvelin et al., 2010; Bracken and Williams, 2013) and positive (Bruno et al., 2005; Arenas et al., 2009; Boyer et al., 2009; Griffin et al., 2009) BEF relationships have been reported within macroalgal assemblages in the context of photosynthetic carbon fixation. Although not using an experiment designed to specifically test the relationship between diversity and productivity, Kraufvelin et al. (2010) observed declining primary production within increasing macroalgal species richness in temperate rocky shores (SE Norway) driven by 
strong identity effects associated with the resident fucoids. A similar relationship was observed by Bracken and Williams (2013) for seaweed assemblages in a northern California (USA) rocky shore, where photosynthetic efficiency was used as an indicator of primary production. Unlike many other studies, experimental species richness gradients were obtained through random allocation (typical of most studies) and non-random methods (mimicking naturally occurring assemblages). While increases in species richness did not lead to changes in function when species were randomly combined, a negative relationship with photosynthetic efficiency was detected when using realistic (non-randomly selected) assemblages (although no relationship was found with maximum photosynthetic rate). Alternatively, Griffin et al. (2009) found that functional diversity of rock pool macroalgae (a measure of the range of species functional traits in the system; Tilman, 2001), rather than species richness, correlated positively with primary productivity. However, the consistency of such BEF relationships may be weakened in natural trophic structures, as typical BEF experiments do not include consumers. Indeed, Reynolds and Bruno (2012) incorporated herbivores in their macroalgal treatments and showed that the positive relationship observed between macroalgal diversity and primary production disappeared in the presence of consumers. Doubt thus remains about the predictability of potentially positive BEF relationships between macroalgae and carbon fixation in real ecosystems.

Regardless of whether species richness (Bruno et al., 2005; Lanari and Coutinho, 2014) or functional diversity (Griffin et al., 2009) is used, species identity appears to be an important driver in determining the rate of primary production in macroalgae (with the exception of Boyer et al., 2009), even when negative BEF relationships are considered (Kraufvelin et al., 2010). Davies et al. (2011) found that individual species biomass explained observed changes in primary production in macroalgae assemblages, and that this could be related proportionally to the effect of changes in single species biomass. This effect was also observed in similar experiments with saltmarsh plants and indicates that biomass may in some circumstances underlie identity effects in primary producer BEF relationships, thereby complicating the importance of biodiversity per se for the sustenance of primary production in such systems.

\subsection{Angiosperms.}

Angiosperm studies provide the only substantial evidence for the role of genetic diversity within BEF relationships for productivity. Positive BEF relationships were apparent between seagrass genetic diversity (Zostera marina) (Williams, 2001; Hughes and Stachowicz, 2004, 
2009; Ehlers et al., 2008; Hughes et al., 2010) and primary productivity, and also between angiosperm species richness (seagrass and transitional angiosperms in the Baltic) and primary productivity (Gustafsson and Bostrom, 2011). Genetic diversity was found to be particularly important for sustaining primary production during stressful conditions or following perturbations (Williams, 2001; Hughes and Stachowicz, 2004; Ehlers et al., 2008; Hughes and Stachowicz, 2009). Reusch et al. (2005) found that genetically diverse treatments also supported more epiphytic fauna, suggesting the influence of genetic diversity can propagate through to changes in secondary productivity. However, Hughes et al. (2010) found that BEF relationships were heavily influenced by grazer species identity. Overall, it is apparent that this relationship cannot be generalized and the context (i.e. the wider system of which angiosperms are part, including grazers) is a determinant factors affecting BEF relationships.

\subsubsection{Ecosystem function: secondary production}

\subsection{Oceanic heterotrophs.}

Within microbial assemblages, about half of the carbon fixed into marine organic matter is consumed by heterotrophic prokaryotes (both direct consumption of primary production and indirect detritus sources). Typically only approx. $20 \%$ of the detrital organic pools used to sustain heterotrophic metabolism is converted into prokaryotic biomass and the majority is respired (del Giorgio and Cole, 1998). Prokaryotic biomass thus transfers some energy and material to the higher trophic levels of the marine food webs (Di Poi et al., 2013) and its metabolism largely contributes to carbon mineralization and respiration rates of benthic ecosystems (Arndt et al., 2013). Investigations of the links between prokaryotic diversity and functioning in marine ecosystems are, however, rare. Available studies indicate a positive relationship between prokaryote diversity and prokaryote carbon conversion efficiency and metabolism (Danovaro and Pusceddu, 2007; Langenheder et al., 2010), i.e. a higher prokaryotic diversity can promote higher levels of secondary production.

Their global distribution, abundance and dominance, makes ciliates among protozoa, and the copepods and euphausiids among metazoa, perhaps the most significant primary consumers. Despite their importance for secondary production (Irigoien et al., 2004; Johnson et al., 2011), nutrient cycling and the translocation of organic matter, there have been no studies examining BEF relationships within these functions. This may be due to difficulties in working with species with small body sizes, occupying intermediate trophic levels and 
detecting small changes in functional output within these components. Although there are some freshwater and tropical studies, there is little to extrapolate these findings to temperate, marine situations.

\subsection{Benthic macrofauna.}

Capture and conversion of pelagic and benthic primary production into benthic secondary production is one of the most important functions undertaken by benthic invertebrates (Fowler and Knauer, 1986). Benthic biomass is in turn consumed by mobile epifaunal species and fish, thereby supporting other trophic levels and pelagic habitats (Townsend and Cammen, 1988). Evidence for clear and consistent relationships between macrofaunal biodiversity and secondary production is lacking, as both positive (O'Gorman et al., 2008; Harvey et al., 2013) and no (Valdivia and Molis, 2009) relationships have been reported.

However these BEF relationships are likely to be of less relevance in relation to the importance of macrofaunal biomass and identity in predicting secondary production, given the well-established paradigm that secondary productivity decreases with increasing macrofaunal size (production to biomass (P:B) ratio increases with a decrease in size, shorter longevity and age of an organism; Jennings et al., 2002; Gray and Elliott, 2009). Thus, it seems that secondary production may more easily be predicted by macrofauna abundance and biomass, and that biodiversity may thus be a less useful predictor for monitoring purposes.

\subsection{Benthic meiofauna.}

The meiofaunal biomass turnover rate is on average 5 times higher than that of macrofauna and, despite having a lower biomass (Giere, 2009), this component frequently exceeds the production of macrofaunal assemblages.

The potential significance of meiofauna in the functioning of benthic sedimentary environments has been examined within relatively low diversity, free-living nematode communities, whose biodiversity (measured through a set of different indices, including, for example, species richness, Shannon diversity, functional diversity as number of trophic traits) is generally related positively with rates of biomass production and heterotrophic prokaryotic carbon production (Danovaro et al., 2008a,b; Pusceddu et al., 2014).

The shape of this positive relationship (linear to exponential functions) varied when habitats from different water depths were considered (Danovaro et al., 2008b). Experimental 
responses of natural nematode assemblages to thermal stress led Gingold et al. (2013) to hypothesize that either (saturating) rivet-like or idiosyncratic relationships are equally probable between nematode species richness and secondary production. Due to the constraints of the manipulative meiofauna experiments, only correlations between free-living nematodes biodiversity and ecosystem functioning have been investigated (Danovaro et al., 2008b; Leduc et al., 2013; Pusceddu et al., 2014). Although nematodes can dominate some meiofaunal communities (e.g. estuaries examined by Alves et al. (2009)), in other habitats they may only account for only a modest contribution to community composition, suggesting that the potential for meiofaunal BEF relationships to exist within these habitats remains largely to be investigated.

\subsection{Benthic epifauna.}

O'Gorman et al. (2008) found that as the diversity of predatory mobile epifaunal fish species increased (with density controlled between treatments), there was an associated increasing trend in secondary production for all intermediate trophic components examined (although only significant for 4 out of the 16 taxonomic components). The level of interference among predators might have been responsible for regulating secondary production between diversity treatments, although there is a possible effect of behavioural changes in feeding activity during confinement within the benthic cages used within the experiement. Using functional diversity, Harvey et al. (2013) found clear monotonic relationships with two functional variables (consumption of macroalgae and of periphyton) which are presumed to generate proportional increases in secondary production in a rocky shore community. Despite very strong identity effects within the functional groups, functional richness did play a substantial role in explained some of the variance in ecosystem functionality during removal treatments (Harvey et al., 2013).

\subsection{Angiosperm epifauna.}

Seagrass habitats provide an additional source of BEF investigations within epiphytic consumer assemblages. Although some studies have failed to find positive BEF relationships between grazer diversity and grazer secondary production (Duffy and Harvilicz, 2001; Duffy et al., 2005, but only in the absence of higher trophic level consumers; Canuel et al., 2007), others have detected them (Duffy et al., 2003, 2005, in the presence of higher trophic level consumers; France and Duffy, 2006). A negative relationship was observed by Duffy and Harvilicz (2001) within mesocosm experiments (lacking trophic levels above the grazers) and it was associated with a low grazer species range (three rather than six species in Duffy et al. 
(2003) and four species in Duffy et al. (2005)), indicating that grazer diversity effects on secondary production may only be apparent at wider ranges of grazer richness (Duffy et al., 2003). The contrasting findings between treatments by Duffy et al. (2005) were influenced by the presence of higher trophic levels. Functioning did increase with richness when higher trophic predators were present. Duffy et al. (2005) suggest that richness is linked to the enhanced epifaunal grazing pressure on resources and the dampening of community fluctuation from predation pressure. France and Duffy (2006) developed this theme by experimentally modifying grazer diversity, dispersal and spatial scale within a metacommunity structure. Richness within meta-community units and, to a less extent, the dispersal potential affected the net productivity at multiple levels within experimental units and large meta-communities.

Most BEF relationships observed, both positive and negative, were underpinned by strong species identity effects that sometimes obscured the influence of species richness alone. It was suggested that the identity effects were mediated through a combination of qualitative and quantitative differences in grazing methods and different population growth rates between species (Duffy and Harvilicz, 2001). Similarly, Canuel et al. (2007) found that identity effects dominated epifaunal grazer functions that convert primary productivity, from seagrass and associated epiphytic algae, into organic matter within the sediment, although with grazer richness and food chain length having little or no influence (the latter finding being in contrast to that of Duffy et al., 2005).

\subsection{Pelagic macrofauna.}

Fish and cephalopods are both opportunistic predators taking zooplankton, macroalgae and other fishes and cephalopod species, and are themselves prey for other organisms (Cury et al., 2003), hence they play a pivotal role in marine food webs by linking lower and upper trophic levels. Cephalopods (particularly squid) have exceptionally high feeding rates (Clarke, 1996; Wells and Clarke, 1996; Hunsicker and Essington, 2008) and also sustain many marine predators, such as bony fish, elasmobranchs, marine birds and mammals, especially whales (e.g. Clarke, 1996; Smale, 1996). Their importance as prey is enhanced by their very high individual growth rates, which, together with other life cycle characteristics (exclusively carnivorous diet, semelparity, short lifespan) leads to high biomass turnover rates or productivity (Boyle, 2002). Despite this, there has been no investigation of BEF relationships between fish or cephalopod diversity and temperate marine secondary production, a fact most likely due to the higher mobility and longer life cycles of these organisms e.g. compared to benthic 
invertebrates, leading to greater difficulties in undertaking manipulation experiments for testing of BEF relationships. Equally, BEF does not appear to have been studied in seabirds and marine mammals.

\subsubsection{Ecosystem process: organic matter removal and transformation}

The transformation of non-living organic matter (both autochthonous and allochthonous sources), typically through detrial consumption, encompasses the essential ecosystem functions that remove and distribute organic matter within an ecosystem (Fig. 1). The consumption of non-living organic matter contributes both to new production and the mobilization of nutrients in the system (Duarte and Cebrian, 1996), typically via the microbial loop (Smith et al., 1992), for re-use in primary production processes. Benthic invertebrate bioturbation (Fig. 2) can also bury matter thereby removing significant amounts of organic matter from the ecosystem (Duarte and Cebrian, 2003).

\subsubsection{Pelagic biological components.}

Organic material produced in the pelagic zone (e.g. as waste products of biological processes) is a resource which is transferred and made available to the benthic system through settlement, with zooplankton faecal pellets being believed to be the main biological vehicle for bentho-pelagic coupling. Aggregates may disintegrate physically (Miligan and Hill, 1998), as well as being solubilized and remineralized by micro-organisms (Smith et al., 1992) and zooplankton (Kiørboe, 2000) whilst settling. A significant amount of dissolved organic matter (DOM) can also be released through inefficient feeding, excretion and defaecation (Saba et al., 2011), which suggests that herbivory might be an important source of bacterial substrate (Lampert, 1978; Gude, 1988). Despite the role of zooplankton in facilitating the flux of organic matter to the seabed, there are no relevant BEF studies investigating the effect of zooplankton diversity of such process. Larger animals also contribute to the horizontal and vertical transfer of organic matter between ecosystems, in the form of living biomass (Stowasser et al., 2005; Hastie et al., 2009). Fish and cephalopods are highly mobile animals and often undertake long feeding and spawning migrations (O'Dor, 1992; Chapman et al., 2012). Combined with their role as intermediate predators in marine food webs, this leads to significant trans-location of organic matter that can affect ecosystem functioning and community structure on a seasonal and regional basis (Hastie et al., 2009). However, as with other ecosystem functions, experimentation difficulties with large and mobile species may have contributed to the lack of BEF evidence for these higher trophic components. 


\subsubsection{Macroalgae and angiosperms.}

Both marine seagrass and macroalgal communities are significant sources of organic carbon to the ecosystem, as more than $85 \%$ of temperate seagrass and macroalgal communities studied by Barr on et al. (2012) supported a net dissolved organic carbon release. Furthermore, there are substantial amounts of macrophyte-generated detritus exported to remote habitats where it provides a substantial organic input (Harrold et al., 1998; Maslo and Lockwood, 2014), e.g. Harrold et al. (1998) observed that significant amounts of macroalgal biomass were being transported from the inshore habitats of production into deep-water canyon systems.

\subsubsection{Benthic macrofauna.}

Macrofaunal species are capable of substantial filtration/gathering of organic matter and sizeable biodeposit production (Widdows et al., 1998; Arntz et al., 1999), especially in densely populated epifaunal communities such as bivalve beds (Giles and Pilditch, 2006). Once consumed, material is either assimilated into biomass or rejected in the form of faeces and pseudo-faeces (Wotton and Malmqvist, 2001). These biodeposits and the benthic invertebrate biomass are available for consumption by other species, hence providing organic transfer between habitats and trophic levels (Snelgrove, 1999). The subsequent flux of bioavailable nitrogen compounds from metabolized biodeposits can be considerable, leading to rapid recycling of nutrients, thereby enhancing rates of primary production and phytoplankton biomass locally (references in Newell, 2004).

With regard to $B E F$ relationships between macrofaunal diversity and organic matter-related ecosystem functions, Godbold et al. (2009) documented a positive BEF relationship between species richness of benthic echinoderms and the use of phytodetrital food sources. Equally, the merging of productivity, decomposition and infiltration (water-drainage characteristics of the saltmarsh) into one metric, termed multifunctionality, by Hensel and Silliman (2013) increased as taxonomically diverse marsh-consuming species were progressively combined within treatments. It was suggested that redundancy within the system was low as each function was controlled by no more than two consumers, and that it is likely that the apparent redundancy is reduced when more ecosystem functions are examined simultaneously. As with almost all of the studies examined, both Godbold et al. (2009) and Hensel and Silliman (2013) stated that functional differences between the species, i.e. identity effects, were responsible for the positive relationships between diversity and functionality. 
2.1.2.4. Benthic microbes. Prokaryotic microbes are mostly responsible for organic decomposition (Cho and Azam, 1988; Arnosti, 2011), especially archaeal assemblages degrading detrital proteins (Lloyd et al., 2013) and recycling organic matter (Takano et al., 2010). As with other microbial ecosystem functions, there are few studies and hence less evidence for the presence of BEF relationships within microbial assemblages. Danovaro and Pusceddu (2007), using prokaryotic diversity (through molecular fingerprinting analysis), observed several positive relationships including one with organic matter decomposition rates. The diversity of free-living nematodes and other meiofaunal species was also found to generally relate positively with rates of organic matter degradation (Danovaro et al., 2008ab; Pusceddu et al., 2014; but in contrast see Leduc et al., 2013 for null relationships).

\subsubsection{Ecosystem process: ecosystem metabolism}

In addition to nutrients and energy needed to support ecosystem functioning, other elements are involved in the metabolic processes behind the production, consumption and decomposition of organic matter (Fig. 2). They can be both essential resources and waste products of other ecosystem functions such as carbon mineralization (using respiratory waste products from all biological components; Table 1), oxygen consumption (metabolic precursor for all biological components) and oxygen production (net excess of photosynthetic waste product from primary producers).

The relationship between carbon assimilation during primary production and oxygen production is expressed by the photosynthetic quotient. This ratio typically lies between 1:1.1 and 1:1.4 (Laws, 1991; Williams and Robertson, 1991), although deviations from these values can be observed depending on the particular primary producer (e.g. macroalgae examined by Rosenberg et al., 1995). Hence net oxygen production is approximately equal to the amount of carbon captured during primary production suggesting that some of the BEF relationships related to primary production might also be relevant for understanding these metabolic functions. However, abiotic factors may substantially control some ecosystem metabolic functions (e.g. the atmospheric control of dissolved oxygen content in open ocean water), suggesting that BEF relationships probably have little influence; this may explain the absence of dedicated BEF studies for these ecosystem functions.

\subsubsection{Macroalgae and angiosperms.}

The dissolved oxygen generated during macroalgal and seagrass photosynthesis exceeds 
overall consumption and constitutes a major contributor for water column oxygenation (Boudouresque et al., 2012). These sources can be particularly important in coastal areas where water bodies range from full oxygen saturation to hypoxia. Seagrass root systems also permeate oxygen into the surrounding sediments, exerting important controls on the depth of the redox transition in coastal areas (Queiros et al., 2011). Based on the relationship provided by the photosynthetic quotient and the BEF evidence with primary production (Williams, 2001; Hughes and Stachowicz, 2004, 2009; Ehlers et al., 2008; Hughes and Stachowicz, 2009), it is likely sea-grass genetic diversity may well also relate to oxygen production. This however is currently untested. There are some freshwater studies examining oxygen production along gradients of macro-algal diversity (e.g. Power and Cardinale, 2009), but there have been no marine studies that have specifically dealt with BEF relationships with this ecosystem function.

\subsubsection{Zooplankton.}

Ammonia excretion, phosphate excretion and, in particular, oxygen uptake by marine zooplankton are body-mass dependent and under the influence of habitat temperature, e.g. $84-96 \%$ of the observed variation in metabolic rate of epipelagic marine zooplankton (lkeda, 1985). Metabolic needs for maintenance are a function of body weight raised by a power function of 0.75 (Kleiber, 1947), hence energy requirements, oxygen consumption and carbon dioxide production decrease proportionally as body size increases. This may suggest again that BEF relationships may not be as important as biomass and/or species identity within certain functions.

\subsubsection{Benthic macrofauna.}

Janson et al. (2012) examined a benthic invertebrate assemblage together with sediment and faunal oxygen uptake rates in a temperate estuarine system. Faunal oxygen uptake correlated positively with the species number of some, but not all, functional groups. Equally, abundance and biomass also correlated with faunal oxygen uptake, suggesting other biotic factors were just as important in modifying oxygen update, and hence carbon mineralization functions, as diversity. However, the dominant influence over the total oxygen uptake was abiotic factors such as grain size, organic matter content and temperature; this suggests that biotic influences on this ecosystem function are proportionally smaller than abiotic factors.

\subsubsection{Benthic microbes.}

Although macroscopic faunal components are important, benthic prokaryotic assemblages in the thin oxic layer of the seabed account for more than half of the total organic carbon 
mineralization (Jørgensen and Revsbech, 1989; Arndt et al., 2013), with respiration rates ranging from 1 to $10 \mathrm{mmol} \mathrm{O} 2 \mathrm{~cm} \sim 3 \mathrm{~d}^{1}$ (Rasmussen and Jørgensen, 1992). Although biodiversity and ecosystem functioning studies have often examined various aspects of ecosystem production, the specific functions relating to oxygen consumption and carbon mineralization have been rarely studied. Leduc et al. (2013) observed no relationships between species and functional nematode diversity with the sediment community oxygen consumption in naturally highly diverse meiofaunal communities along the upper slope off New Zealand. This was in contrast to the positive relationships detected by Danovaro et al. (2008b) and Pusceddu et al. (2014) within higher diversity meiofaunal assemblages, suggesting a breakdown of the exponential BEF relationship at high levels of diversity, which may be due to increased competition or greater functional redundancy (Leduc et al., 2013).

\subsubsection{Ecosystem process: nutrient cycling}

The C:N:P stoichiometry of phytoplankton ultimately controls the water column nutrient ratios, which are subsequently modified by microbial reactions such as the microbial degradation of settling material, nitrification, anaerobic ammonium oxidation ('anammox')/denitrification and nitrogen fixation (Fig. 1). These microbial processes can significantly influence the overall budget of nitrogen availability and can generate significant differences between oceanic regions (Gruber and Sarmiento, 1997). The physical processes, such as the bioturbation of sediments by benthic invertebrates (Table 1), can also increase the flux of nutrients released from sediment-based, microbial processes (Gray and Elliott, 2009).

\subsubsection{Ecosystem function: denitrification, nitrification and nitrogen fixation.}

As denitrification is inhibited in the presence of oxygen, this process only occurs within anoxic water and sediment conditions (Tiedje,1988). By contrast, nitrogen fixation occurs in all of the oceanic basins (Gruber and Sarmiento, 1997), with a major contribution from the marine diazotrophic cyanobacterium Trichodesmium spp. (Carpenter, 1983) and secondarily from diatom genera Rhizosolenia and Hemiaulus (containing the endosymbiotic nitrogen fixing cyanobacteria Richelia intracellularis) (Arrigo, 2005 and references therein), accounting overall for an estimated increase in the current global supply of nitrogen by $28 \mathrm{Tg} \mathrm{N} \mathrm{yr}^{-1}$ (Gruber and Sarmiento, 1997). Seagrass meadows are also zones of intense nitrogen fixation which can significantly contribute to the overall primary production (Welsh, 2000). Despite the importance of denitrification, nitrification and nitrogen fixation in determining the availability of nitrogenous products to other ecosystem processes, these functions have yet to be examined in relation to 
biodiversity gradients. This paucity probably reflects the difficulty in defining microbial biodiversity and measuring functional output within experimental manipulations.

\subsubsection{Exchange of limiting nutrients}

\subsection{Phytoplankton.}

The availability of limiting compounds is also heavily modified by primary producer uptake and vice versa. In addition to the use of inorganic sources, various phytoplankton species can use dissolved organic nitrogen directly to meet their $\mathrm{N}$ needs and heterotrophic uptake of dissolved organic carbon has been observed in a number of dinoflagellates (Lewitus and Caron, 1991) and chrysophytes (Wheeler et al., 1977; Kristiansen, 1990). Bacterioplankton (Liu et al., 2010; Tappin et al., 2012) and phytoplankton (Mulholland and Lee, 2009) can directly utilize oligopeptides by both external hydrolysis and direct assimilation depending on molecular size. Ptacnik et al. (2008) and Goebel et al. (2014) found positive BEF relationships in the phytoplankton. Using more than 3000 natural phytoplankton samples, Ptacnik et al. (2008) found that the amount of algal carbon per unit total phosphorus was positively related to genus richness suggesting a positive relationship between phytoplankton diversity and resource use efficiency of the phytoplankton communities in freshwater environments and the Baltic Sea. Goebel et al. (2014) also observed positive, asymptotically saturating relationships between ecosystem-wide phytoplankton diversity and nutrient uptake. Complementarity, and specifically facilitation, interactions between coexisting phytoplankton types were found to underlie much of the positive relationship (Goebel et al., 2014).

\subsection{Macroalgae and angiosperms.}

Macroalgal species assimilate both nitrate and ammonium from the water column (Naldi and Wheeler, 1999). Annual macrolagae act as carbon and nutrient (mainly nitrogen and phosphorus) sinks during bloom periods and subsequently become sources during die-off periods through leaf shedding, grazing and mechanical breakage of leaves.

Perennials, particularly those capable of forming dense stands such as kelp forests, also represent significant elemental pools. Both positive and negative BEF relationships have been documented within macroalgal assemblages. Bracken and Stachowicz (2006) observed a positive relationship between species richness and nitrogen assimilation, but only when both ammonium and nitrate uptake rates were examined simultaneously, indicating increased resource partitioning and hence complementarity within intertidal macroalgal assemblages. By contrast, a decrease in nutrient uptake with increasing 
seaweed species richness was detected by Bracken and Williams (2013) on rocky shores. This negative relationship was only apparent when they used realistic, non-randomly assigned, species richness for treatments. This suggests that random species allocation to treatments, typical of many BEF experiments, may significantly change the expression of BEF relationships, potentially confounding many BEF findings.

Seagrasses are capable of assimilating nitrogenous sources from both roots and leaves, although the uptake from the sediment, via the roots, is the major source (e.g. Zostera marina; Short and McRoy, 1984). Positive relationships were also highlighted between seagrass (Z. marina) genetic diversity and nutrient cycling (Hughes and Stachowicz, 2004; Hughes and Stachowicz, 2009). As shown with other functions, genetic diversity was particularly important following disturbance as pore water ammonium concentrations also decreased with increased genetic diversity after disturbance (Hughes and Stachowicz, 2004).

\subsection{Benthic macroalgae.}

Although sediment microbial activity is recognized as the main source of nutrients to the overlying water column, ammonium excretion from benthic invertebrates can be a significant contribution to this recycling function (Wotton and Malmqvist, 2001; Jordan et al., 2009). The flux of nutrients, liberated by microbial processes within the sediment, can be significantly enhanced by macrofaunal bioturbation processes (Birchenough et al., 2012). Bioturbation can enhance nutrient cycling by as much as 35\% (Guti errez et al., 2011), and nutrients derived in this way can contribute up to $80 \%$ of those required by pelagic primary producers (Dale and Prego, 2002). With the exception of one study (Bolam et al., 2002), positive relationships between benthic invertebrate species richness and nutrient sediment flux were present in several studies including Emmerson and Raffaelli (2000) (ammonium flux), Waldbusser et al. (2004) (inverse phosphate flux), leno et al. (2006) (ammonium and phosphate), Bulling et al. (2010) (ammonia only but not with phosphate) and Karlson et al. (2010) (nutrient incorporation within the sediment through biodeposit production). In all of these studies, except for Karlson et al. (2010), identity effects underpinned the observed BEF relationships, highlighting the overwhelming importance of the role of individual species in affecting nutrient fluxes rather than species richness per se. Although failing to detect either a positive or negative BEF relationship, Bolam et al. (2002) also suggested identity effects were present and, expressed through functional diversity, are important in maintaining nutrient fluxes. By contrast, Karlson et al. (2010) concluded that the positive, 
over-yielding relationship between benthic macrofaunal deposit feeders and phytodetrial processing observed was mainly explained by niche partitioning and/or facilitation (complementarity) rather than identity effects.

The importance of the role of individual species (hence identity effects) within infaunal BEF relationships was also highlighted by Biles et al. (2003) who examined both species and functional richness against ammonium release from sediments. In fact, while there was not a relationship between nutrient flux and species richness, the use of functional richness (trait diversity) produced a stronger, positive association with the studied ecosystem function, thus highlighting the potential value of traits analysis to provide biodiversity measures for BEF assessment while compensating for identity effects (Biles et al., 2003; Hensel and Silliman, 2013). However, Emmerson et al. (2001) showed that the effect of either benthic species richness or functional diversity on ammonia release in intertidal areas varied spatially, with highly idiosyncratic relationships occurring in different sites. Similarly Queir os et al. (2011) highlighted the influence of habitat complexity and sediment type on the relative role of infaunal species as drivers of function. Hence, geographic location (and associated abiotic environmental features) and species identity can significantly affect the expression of BEF relationships, especially when underpinned by identity effects, therefore they need to be taken into account while attempting to operationalize BEF relationships for monitoring purposes.

\subsection{Pelagic biological components.}

There are few studies examining BEF relationships in fish, cephalopod, seabird, reptile and mammal assemblages. This is probably due to the difficulty of experimental manipulations with these animals in controlled conditions, their occupation of higher trophic levels and possibly their probable small contribution to these functions (Table 1). In studies other than temperate marine habitats, Mclntyre et al. (2007) (tropical freshwater lake system) and Allgeier et al. (2014) (tropical habitat) both found that declining fish diversity reduced nutrient recycling processes. These relationships were dominated by identity effects with relatively few species dominating nutrient recycling (Mclntyre et al., 2007; Allgeier et al., 2014).

\subsubsection{Ecosystem process: physical environmental modification}

Many species provides habitat for others, such as dense vegetated habitats generated by macroalgal and angiosperm beds (Table 1). Species adding complexity to seabed habitats tend to accentuate BEF relationships by promoting additional diversity, which in turn can 
lead to elevated functioning (Kochmann et al., 2008; Rilov et al., 2012). These so-called 'ecosystem engineer' species may also have a disproportionate effect on the physical environment, which can improve conditions for other species or significantly change other functional rates (Fig. 2).

\subsubsection{Ecosystem function: reef building, water velocity and particle flux/sedimentation modification.}

Epifaunal benthic invertebrates can be found in extremely high densities and generate biogenic structures that can influence the physical environment and provide important habitat for other species (Rigolet et al., 2014). The rugosity (complexity) and elevation of some of these structures is sufficient to reduce flow rates and resuspension and increase accretion (Wildish and Kristmanson, 1984). Macroalgae, such as the fucoids (order Fucales) intertidallyand kelps (order Laminariales) subtidally, are the main foundation species on most temperate hard substrata habitats (Jones et al., 1994). Both of these macrophyte groups modify environmental parameters, for example, by providing moist intertidal microclimates during emersion (Jenkins et al., 1999); modification of boundary conditions, sedimentation and shoreline stabilization (Hull, 1987; Boudouresque et al., 2012; Infantes et al., 2012; Jackson et al., 2013) and also providing a physical structure for colonization (Epifanio et al., 2003; Rabaut et al., 2007).

With regard to BEF relationships within the context of provision of physical habitat, Williams (2001) found a positive association between intra-specific genetic diversity within Zostera marina and leaf shoot density. Although Hughes and Stachowicz (2004) failed to find the same relationship under normal growth conditions, following a period of intense grazing by wildfowl, they did find that more leaf shoots, and hence greater habitat provision, remained in plots with higher genetic diversity, suggesting greater resistance in these treatments. The greater remaining biomass may also lead to a greater output of other functional products. There are no studies that have examined benthic invertebrate diversity and habitat provision.

\subsubsection{Ecosystem function: biomodification of the sediment matrix.}

Biomodification of the sediment matrix through bioturbation, bioirrigation, biodeposition and biostabilisation (Gray and Elliott, 2009) are fundamental infaunal processes with implications for a range of ecosystem functions. These activities exert significant influence over benthic sedimentary geochemical environments through impacts on oxygen, $\mathrm{pH}$ and redox gradients (Lohrer et al., 2004; Stahl et al., 2006; Pischedda et al., 2008; Queir os et al., 2011; Birchenough et al., 2012), contaminant sequestration and release (Teal et al., 2009) and 
sediment granulometry (Montserrat et al., 2009), biomodification processes affect bacterial activity and composition (Mermillod-Blondin, 2011; Gilbertson et al., 2012), carbon (Kristensen, 2001) and nitrogen cycling (Gilbert et al., 1998; Emmerson and Raffaelli, 2000). As with the nutrient fluxes discussed above, there are positive relationships between species richness and sediment oxygenation/sediment mixing, as indicated by the depth of the redox potential discontinuity layer (Waldbusser et al., 2004; Godbold and Solan, 2009). Waldbusser et al. (2004) also observed that the variability of the oxygen flux was reduced in the multispecies treatment, indicating that richness may also stabilize certain ecosystem functions. Both Waldbusser et al. (2004) and Godbold and Solan (2009) suggest that the positive influence of species richness on ecosystem function was again a product of identity effects mediated through functional traits, and that higher levels of biodiversity reduce the relative influence of abiotic factors (Godbold and Solan, 2009).

\subsubsection{Conclusions for operational requirement 1}

The evidence for BEF relationships within different functions and for all biological components has been summarized in Table 3. Biodiversity and ecosystem function relationships, stemming from both taxonomic and functional diversity measures, were demonstrated in the literature for several functions and biological components. The vast majority of the reported relationships were positive. However, not all components or functions were involved, with notable knowledge gaps that might inhibit the development of mechanisms that could convert biodiversity measures to holistic and realistic surrogates of ecosystem function: this may ultimately prevent the application of BEF relationships for practical monitoring roles.

In some cases, the evidence supporting positive BEF relationships was sparse or inconsistent (e.g., large variability in the response of the relationships between meiofaunal biodiversity and secondary production), with limited representativity of the geographic area (e.g., positive relationship between angiosperm species diversity and primary production was available for tropical and Baltic areas only) or the marine habitat (e.g., nutrient recycling and fish diversity in freshwater).

Methodological influences were also apparent and were due to: (1) the small number of species typically used in BEF experiments (see Stachowicz et al., 2007); (2) the definition and number of ecosystem functions used (few studies are multi-functional); (3) the use of random or realistic biodiversity gradients; (4) the type of experiments (laboratory, mesocosm or field 
trials); (5) experimental duration; (6) spatial replication, (7) an absence of the simultaneous testing of abiotic factors, and (8) the number of trophic levels included (see below). These all contributed to occasionally over-powering contextual dependency, further complicating the determination of over-arching BEF relationships.

In several cases, trophic interactions added complexity and ambiguity to BEF relationships, preventing clear generalizations between studies. As well as BEF relationships changing the availability of functional products within an ecosystem, biodiversity itself can directly influence trophic dynamics. As food web size increases (measured by the number of species) the number of feeding links per species (linkage density) also increases (Christensen and Pauly, 1993). This increases the abundance of prey available to predators in species rich food webs and may also have implications for redundancy within the system. Therefore, food webs with higher biodiversity may both increase in overall available resource and have a higher connectivity between trophic levels allowing for more routes for the movement of these resources. For example, Finke and Denno (2004), Hillebrand and Cardinale (2004), Spivak et al. (2007), O'Gorman et al. (2008), Edwards et al. (2010), Reynolds and Bruno (2012) and Hensel and Silliman (2013) all found that changes in species richness at differing trophic levels also induced structural and functional changes in adjoining levels. Changes in both the resource distribution within a food web (via BEF boosted functions) and the structural changes associated with diversity changes alone might induce or modify 'trophic cascades', thereby complicating the expression of biodiversity induced changes to ecosystem functioning. In contrast, Borer et al. (2005) and O'Connor and Bruno (2009) did not observe trophic changes with species richness. The meta-analysis of terrestrial and marine studies by Borer et al. (2005) indicated that predator and herbivore taxonomy and physiology were more influential in stimulating cascades than richness. The complexity of both trophic dynamics and BEF relationships makes it particularly difficult to predict overall ecosystem functioning with increasing biodiversity in one or multiple biological components (Snelgrove et al., 2014). On balance, there are many studies to support the BEF premise that biodiversity does influence ecosystem function. Negative relationships were rarely evident or reported when compared with positive relationships.

\subsection{Operational requirement 2: what biological components are required to represent biodiversity within a BEF relationship?}

Biodiversity is routinely represented and deconstructed into measureable, manageable 
and meaningful components. Biodiversity assessments often focus on specific components (e.g., benthic infauna, angiosperms, and fish) which are assumed to be representative or proxies for the biodiversity of the ecosystem as a whole. Measuring a component of the system is usually easier and more cost effective than measuring the overall system biodiversity, considering also that the expertise of the researchers undertaking the assessment is often limited to one or few biological components. Translating BEF relationships into workable monitoring applications requires that the biodiversity components selected are also relevant to the given BEF relationship. It is therefore necessary to identify which biological components are required to represent biodiversity within a given BEF relationship of interest. For example, the use of angiosperms alone for estimating total regional primary production will be inadequate unless phytoplankton and macroalgae can also be combined, as they can significantly contribute to this function. It is therefore necessary to establish: (1) what biological components are needed to be selected to represent biodiversity for assessing a particular ecosystem function, and (2) what is their relative importance in influencing and contributing to the overall functional output.

Different biological components can contribute to the same ecosystem function (e.g. phytoplankton, macroalgae and angiosperms all contribute to primary production) although specific biotic attributes may modify and scale its functional contribution (Table 1). These include: (1) its spatial extent within multiple habitats; (2) presence (biomass or abundance/body size), and (3) functional rate. These factors were considered to rank the relative contribution of the different biological components to each ecosystem function (Table 1 ), as informed by the BEF literature review. Due to the high variability in the measurement units characterizing these attributes within the reviewed studies, and given the need of obtaining comparable data across the different components, functions, and studies, a rigorous quantitative assessment method could not be applied, and a scoring system was used based on semi-quantitative criteria, with a certain degree of expert judgement also involved (Table 2). In particular, the spatial extent of a biological component was scored based on its degree of occurrence at both the habitat and regional scales (Table 2), under the assumption that, although different components can be locally important, those that are more widespread and resident in multiple habitats are more likely to contribute to an ecosystem function at the regional level, in line with the scale of assessment required for regional marine monitoring. 
Table 2. Criteria used to estimate the spatial extent, presence and functional rate of biological components examined by ecosystem function.

\begin{tabular}{|c|c|c|c|c|c|c|c|c|}
\hline \multirow[t]{2}{*}{ Score } & \multicolumn{2}{|l|}{ Spatial extent } & \multicolumn{2}{|l|}{ Presence } & \multicolumn{4}{|c|}{ Functional rate } \\
\hline & Regions & Habitats & Body size & Abundance & Body size & Limitation & Primary production & Secondary production \\
\hline 1 & Few regions & Some habitats & Micro & Low & Mega & Low/high & +0.5 & -0.5 \\
\hline 2 & Some regions & Some habitats & Micro & High & Macro & High & +0.5 & -0.5 \\
\hline 3 & Some regions & Many habitats & Macro & Low & Macro/micro & Low & +0.5 & -0.5 \\
\hline 4 & Many regions & Some habitats & Macro & High & Micro & High & +0.5 & -0.5 \\
\hline 5 & Many regions & Many habitats & Mega & - & Micro & Low & +0.5 & -0.5 \\
\hline
\end{tabular}

Presence was scored based on the relative biomass typically characterizing a biological component (Table 1). This was assessed by its relative biomass or abundance and body size. These were estimated from two generic relationships with trophic position. Firstly, that the average body size increases with trophic level (for example, Romanuk et al. (2011) for fish and France et al. (1998) for aquatic benthic communities) although it is recongnised that this is not always a consistent relationship (e.g. Layman et al. (2005) did not observed this relationship within a freshwater food web). And secondly that the biomass and/or abundance varies with trophic position (Odum et al., 1971). This can be a decreasing abundance with increasing trophic position to generate the typical 'trophic pyramid', or an inverted trophic pyramid, that are typical of marine food webs based on phytoplankton and especially those in oligo- trophic areas (Gasol et al., 1997 although also see Mara n on et al., 2001 for a conflicting view).

The assessment of functional rate by each biological component, using body size as a proxy (assuming increasing rates with decreasing body size (Kleiber, 1947)) is important given the potential variability in the rate of function regardless of 'presence'. For example, the relative presence of ocean phytoplankton can be low in terms of biomass due to high turnover rates (Odum et al., 1971; Gasol et al., 1997; Field et al., 1998), but the high growth/functional rate and wide spatial extent makes the phytoplankton a critical and significant contributor to primary production in marine ecosystems (Gasol et al., 1997). Finally, spatial extent has been considered as the third variable that determines the ecosystem functioning value of a biological component. For example, although angiosperms and macroalgae have high growth rates and standing biomass, they are confined to a limited number of habitats and regions, thereby decreasing their regional contribution to primary production, hence their lower score compared to phytoplankton (Table 1).

Finally, ecosystem functions that are disproportionately influenced by aspects of spatial 
extent, presence or rate have been adjusted using expert judgement. For example, functionality provided by physical engineering may be more related to presence (biomass/abundance), whereas biogeochemical processes may be more dependent on processing rates (e.g. of nutrient cycling, organic matter decomposition). By providing a framework for contextualizing individual biological components within multi-component systems, Table 1 aids in the selection of the required biological components and practical application of BEF relationships into monitoring programmes. This is a simplistic attempt to examine functional output by biological component that does not include the interactions between biological components and functions (e.g., the availability, routes or processes that the products of a certain function are subsequently used within). In addition, these results, in combination together with the gaps in BEF evidence highlighted above for certain biological components and functions, indicate research priorities to allow the appropriate assessment of ecosystem functioning at the regional level. For example there is a lack of studies examining the microbe, phytoplankton and zooplankton assemblages, which, according to Table 1, may have a primary contribution to several ecosystem functions.

\subsubsection{Conclusions for operational requirement 2}

The scoring of the biological components indicates that the large BEF evidence gaps align with several of the more functionally important components. For example, microbial processes generating primary and secondary production, phytoplankton trans-location of organic matter, zooplankton secondary production and the physical engineers of habitats by benthic invertebrates. Hence for many of the main ecosystem functions, there is insufficient evidence for enough contributing biological components to adequately represent 'biodiversity' in many BEF relationships. The approach in Table 1 needs further development to provide a confident 'look-up' tool for practical applications using BEF relationships.

\subsection{Operational requirement 3: can the biodiversity of the selected biological components be measured easily?}

Having selected the appropriate biological components for a given BEF relationship of interest, monitoring methodologies require that biodiversity of those components can be assessed and expressed in compatible units. Measures of biodiversity used in most reviewed studies appear straightforward at the macroscopic scale (e.g. macrofaunal species richness) and have tangible relationships with several ecosystem functions. However, defining and measuring biodiversity in consistent and meaningful units for the microscopic biological 
components, such as the microbial assemblages, and at the genetic scale, poses significant challenges. For example, most of the prokaryotes cannot be identified by cultivation-based approaches but require molecular analyses (16S rRNA genes). Recently, the transition from Sanger sequencing to the next generation of high throughput sequencing technologies has opened new horizons in exploring the biodiversity of prokaryotic assemblages (Giovannoni and Stingl, 2005; Sogin et al., 2006; Roesch et al., 2007; Caporaso et al., 2010). Next generation sequencing technologies applied to 16S rRNA genes have not only increased the current databases, but also allows the identification of rare bacterial taxa for which ecological significance is even more uncertain than that of the dominant taxa (Sogin et al., 2006; Gobet et al., 2012).

Overall, monitoring applications incorporating BEF relationships require that the biodiversity measures of the biological components selected are consistent, cost-effective to monitor and calculate, and mechanisms to control the bias associated with sampling limitations are in place. It is clear that the working monitoring tools, based on BEF relationships, will potentially span several biological components and that this must ultimately be represented as comparable and easily obtained measures of biodiversity. The difficulty in defining biodiversity units within functionally important components, such as microbes, not only prevents the development of practical BEF-based applications, but also compromises the development of the underlying evidence base. Furthermore, insufficient knowledge is available on the other measures of biodiversity, such as genetic or guilds, to establish the most appropriate measure of biodiversity for the combined component approaches.

\subsection{Operational requirement 4: how does biodiversity generate ecosystem function relationships?}

Depending on the underlying BEF relationship mechanism, standard units used to describe structural elements of biodiversity may not have the most direct relationship with specific functions and therefore may require expression as alternative measures of biodiversity. For example, BEF relationships underpinned by identity effects are often irregular (similar to riveted BEF models) when maintained in structural biodiversity units. In this situation, taxonomic units may benefit from translation into functional diversity using traits-based analysis, such as Biological Traits Analysis (e.g. Bremner, 2008), into more standardized units that have a more uniform and linear relationship with ecosystem functioning. For BEF relationships emerging from complementarity, direct (taxonomic) measures of biodiversity, such as species 
richness, may be sufficient to express the influence of biodiversity. Therefore, operational use of BEF relationships requires: (1) that the mechanism of delivery for each BEF/biological component combination is known, and (2) that the units used to express biodiversity best represent the mechanisms that underpin positive BEF relationships.

Unlike many of the terrestrial studies where complementarity is prevalent (Cardinale et al., 2007), positive marine BEF relationships examined in the marine environment (this study and others, e.g. Stachowicz et al., 2007; Cardinale et al., 2012; Gamfeldt et al., 2014) are mostly driven by identity effects (Table 3 ). In many studies, the increased functional rates observed were mostly ascribed to the presence of particular species (and their associated functional abilities or traits), rather than to an increase in species diversity (e.g. richness) per se. As a result, functional diversity has been used on several occasions within BEF research (e.g. through Biological Traits Analysis, BTA) (Emmerson and Raffaelli, 2000; Emmerson et al., 2001; Bolam et al., 2002; Godbold and Solan, 2009; Harvey et al., 2013). When compared with species richness, the expression of biodiversity as functional diversity has often provided a better relationship with ecosystem functionality (Griffin et al., 2009).

However, despite this, identity effects were still apparent in some of these studies (Norling et al., 2007; Griffin et al., 2009), suggesting that trait-based analysis is insufficient to fully capture the underlying properties that generate identity effects. Functional triats, or roles, are often repeated across species within assemblages, suggesting that different species differ in either their functional performance or influence. For example, Tornroos et al. (2014) found that $66 \%$ of all of the possible traits measured in marine benthic macrofaunal species (in Northern Europe) were still expressed despite a reduction in species richness from 151 to 6 taxa, indicating that most traits (hence functional roles) are shared and categorical descriptions of species role are replicated within natural assemblages. This suggests that identity effects are not just an expression of the species functional role, as assessed with BTA, but also 'role performance' and/or 'role influence' are relevant in determining the species contribution to the overall functioning of the system. The rate, efficiency or influence of a particular role is not coded within BTA, and this is understandable considering how the performance of any species can change depending on numerous factors including age, abundance, habitat, community composition and environmental conditions (Queir os et al., 2011).

Despite the difficulty of attributing species with both categorical functional roles (e.g. BTA) and quantitative information of role performance or influence, these approaches demonstrate a 
greater capability to detect and compensate for identity effects in BEF relationships, thus allowing ecosystem function to be estimated from species information. Furthermore, species providing disproportionate contributions to overall functionality can be identified from structural community data rather than from functional response experimentation. Knowing when and which species are functionally important allows for focused species-based monitoring and management. Furthermore, if the information on role, performance/influence and pressure sensitivity of species can be combined, it should also be possible to model, and therefore predict, the vulnerability of functionally important species and the expected loss of ecosystem functionality along a realistic gradient of species loss. 
Table 3. Biodiversity and ecosystem function relationship evidence summary table for the eight biological components.

\begin{tabular}{|c|c|c|c|c|}
\hline & & BEF evidence & Mechanism & Additional observations \\
\hline \multirow[t]{2}{*}{$\begin{array}{l}\text { Biomass } \\
\text { production }\end{array}$} & Primary productivity & $\begin{array}{l}\text { Phytoplankton }{ }^{1} \\
\text { Macroalgae }^{2} \\
\text { Angiosperms - genetic } \\
\text { diversity }^{3} \\
\text { Angiosperms - species } \\
\text { diversity }^{4}\end{array}$ & $\begin{array}{l}\text { Identity + } \\
\text { complementarity } \\
\text { Identity > } \\
\text { complementarity } \\
\text { Not known } \\
\text { Identity (species } \\
\text { only) }\end{array}$ & $\begin{array}{l}\text { Measuring biodiversity problematic } \\
\text { Both species and functional richness } \\
\text { Particularly important during } \\
\text { disturbance/stress } \\
\text { Tropical and Baltic studies only }{ }^{4}\end{array}$ \\
\hline & $\begin{array}{l}\text { Secondary } \\
\text { productivity }\end{array}$ & $\begin{array}{l}\text { Microbes }^{5} \\
\text { Benthic invertebrates }\end{array}$ & $\begin{array}{l}\text { Not known } \\
\text { Identity > } \\
\text { complementarity }\end{array}$ & $\begin{array}{l}\text { Measuring biodiversity problameatic } \\
\text { Meiofaunal evidence sparse }\end{array}$ \\
\hline \multirow[t]{2}{*}{$\begin{array}{l}\text { Organic } \\
\text { matter } \\
\text { transformation }\end{array}$} & $\begin{array}{l}\text { Organic matter } \\
\text { decomposition and } \\
\text { removal }\end{array}$ & $\begin{array}{l}\text { Microbes }^{7} \\
\text { Meiofauna }^{8} \\
\text { Benthic macro- } \\
\text { invertebrates }^{9} \\
\end{array}$ & $\begin{array}{l}\text { Not known } \\
\text { Not known } \\
\text { Identity }\end{array}$ & $\begin{array}{l}\text { One study only } \\
\text { Conflicting evidence } \\
\text { One study only }\end{array}$ \\
\hline & $\begin{array}{l}\text { Import/export of } \\
\text { organic matter }\end{array}$ & No evidence & & \\
\hline \multirow[t]{2}{*}{$\begin{array}{l}\text { Ecosystem } \\
\text { metabolism }\end{array}$} & $\begin{array}{l}\text { Oxygen } \\
\text { consumption and } \mathrm{C} \\
\text { mineralisation }\end{array}$ & No evidence & & $\begin{array}{l}\text { of abiotic factors for some of these } \\
\text { ecosystem functions may suggest that } \\
\text { BEF relationships have little influence } \\
\text { and may explain the absence of } \\
\text { dedicated studies for these ecosystem } \\
\text { functions. }\end{array}$ \\
\hline & Oxygen production & No evidence & & \\
\hline \multirow[b]{4}{*}{$\begin{array}{l}\text { Nutrient } \\
\text { cycling }\end{array}$} & Denitrification & No evidence & & \\
\hline & Nitrification & No evidence & & \\
\hline & Nitrogen fixation & No evidence & & \\
\hline & $\begin{array}{l}\text { Exchange of limiting } \\
\text { nutrients }\end{array}$ & $\begin{array}{l}\text { Phytoplankton } \\
\text { Macroalgae }^{11} \\
\text { Angiosperms }^{13} \\
\text { Benthic invertebrates }^{14} \\
\text { Fish }^{15}\end{array}$ & $\begin{array}{l}\text { Complementarity } \\
\text { (facilitation) } \\
\text { Complementarity } \\
- \\
\text { Identity > } \\
\text { complementarity }\end{array}$ & $\begin{array}{l}\text { Limited evidence base } \\
\text { Additional trophic levels modified the } \\
\text { BEF relationship }{ }^{12} \\
\text { Genetic diversity } \\
\text { Both species and functional richness }{ }^{19} \\
\text { Evidence from a freshwater and }\end{array}$ \\
\hline
\end{tabular}




\begin{tabular}{|c|c|c|c|c|}
\hline & & & Identity & tropical system $^{15}$ \\
\hline \multirow{3}{*}{$\begin{array}{l}\text { Physical } \\
\text { engineering }\end{array}$} & Bioturbation & Benthic invertebrates ${ }^{14 \& 16}$ & Identity & $\begin{array}{l}\text { Reduced variability with richness also } \\
\text { documented }^{17}\end{array}$ \\
\hline & Reef building & $\begin{array}{l}\text { Angiosperms - genetic } \\
\text { diversity }^{18}\end{array}$ & Not known & $\begin{array}{l}\text { Conflicting evidence from normal and } \\
\text { disturbed conditions }\end{array}$ \\
\hline & $\begin{array}{l}\text { Water velocity, } \\
\text { particle flux and } \\
\text { sedimentation }\end{array}$ & No evidence & & \\
\hline
\end{tabular}

References

1 Balvenera et al., 2006; Cardinale et al., 2006; Hector et al., 2007

2 Bruno et al., 2005; Arenas et al., 2009; OLanari and Coutinho, 2014

3 Hughes et al., 2009; Williams, 2001

4 Terrados et al., 1998; Duarte et al., 2000; Gustaffsson and Böstrom, 2011

5 Danovaro and Pusceddu 2007; Langenheder et al., 2010

6 Duffy et al., 2003; Duffy et al., 2005; France and Duffy, 2006 ; Gorman et al., 2008; Harvey et al., 2013; Hensel and Silliman, 2013

7 Danovaro and Pusceddu, 2007

8 Danovaro et al., 2008; Pusceddu et al., 2014

9 Solan et al., 2004; Godbold et al., 2009; Queirós et al., 2011; Hensel and Silliman, 201310 Ptacnik et al., 2008

11 Grififn et al., 2009; Bracken and Stachowicz, 2006

12 Reynolds and Bruno, 2012

13 Hughes et al., 2009

14 Emmerson and Raffaelli, 2000; Waldbusser et al., 2004; leno et al., 2006; Bulling et al., 2010; Karlson et al., 2010

15 Mclntyre et al., 2007 (freshwater lake system); Allgeier et al., 2014 (trophical system)

16 Waldbusser et al., 2004; Godbold and Solan, 2009

17 Waldbusser et al., 2004

18 Williams, 2001

19 Biles et al., 2003 
2.5. Operational requirement 5: what proportion of the overall variance of a given function is explained by biodiversity?

Although a BEF relationship may be present for a particular function, there is also a need to determine the contribution made by biodiversity to the total expression of a particular ecosystem function. It is possible to detect a BEF relationship (operational requirement 1) yet have it only explain a very small proportion of the functional variance because other factors, such as abiotic variables, actually dominate the functional rates (Fig. 3).

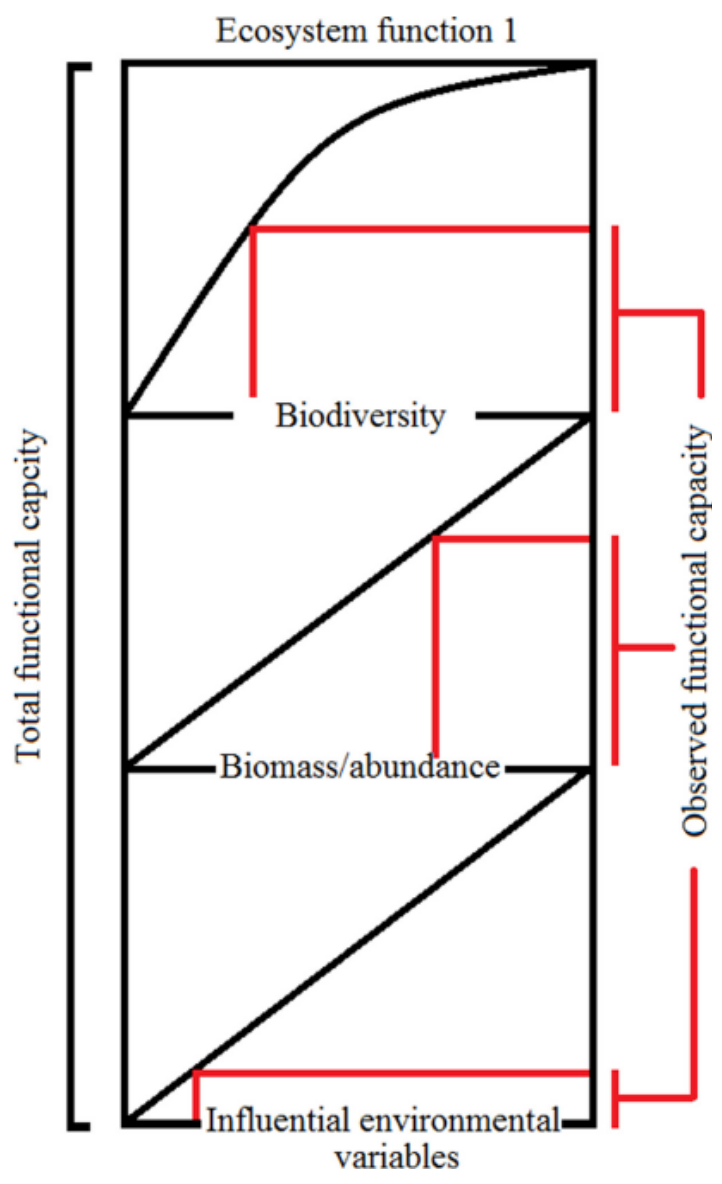

Fig. 3. Representation of overall capacity for a single ecosystem function as a composite of three equally important contributing factors. Hypothetical contribution of each factor is shown in red. (For interpretation of the references to colour in this figure legend, the reader is referred to the web version of this article.) 
This review shows that studies rarely measure or consider the magnitude of the biodiversity influence on ecosystem functions compared to other abiotic or biotic factors (Fig. 3). Hence it is not possible to determine the overall importance of operationalized BEF measures within the total ecosystem functioning observed. Where abiotic factors have been also considered, it was clear that these may modify the BEF relationship and have their own direct influence on functional rate (Biles et al., 2003; Godbold and Solan, 2009; Bulling et al., 2010; Queiros et al., 2011). As such, the effects of biodiversity may be of secondary importance when compared to the influence of other abiotic and biotic drivers of ecosystem function (Godbold, 2012) and may also be substantially transformed under changing abiotic regimes (Gamfeldt et al., 2014). Practical monitoring applications using BEF relationships require that the contribution of all of the factors (biodiversity, abundance and abiotic variables) to ecosystem functioning are quantified and any interactions between factors are known and can be compensated for.

The influence of biodiversity on ecosystem functioning is further complicated as different functions will interact in an ecosystem, hence an increase in the functional output within one ecosystem function may change the availability of resources or substrate for use in other ecosystem functions. At the same time, this 'spill-over' enhancement effect can be modified by resource availability, with scarce or limited resources likely generating the greatest spill-over augmentation. For example, an increase in nitrogen fixation will also enhance primary and secondary production locally, the potential enhancement or 'spill-over' in this case being determined by the amount of nitrogen fixed and the existing availability of nitrogen locally. In contrast, dissolved oxygen for respiration may already be sufficiently available from the atmospheric input that further biological inputs induce little or no functioning benefit. It is also possible that the excessive supply of functional product resources may in fact become detrimental to some adjoining trophic levels. For example, the metabolic production of ammonium may benefit autotrophs but potentially be toxic to heterotrophs. Furthermore, some functional products may be in a form that is unavailable for subsequent reprocessing. Phytoplankton biomass is rapidly consumed by the zooplankton, however, the biomass produced in seagrass beds is often high in refractory carbon and rarely consumed by secondary producers directly (Kennedy and Bj ${ }^{\epsilon}$ ork, 2009).

The interactions outline above increase the difficulties in obtaining accurate predictions about the value of BEF-induced functional spill-over to other biological components/trophic levels. With regard to practical application of BEF relationships and meaningful reporting, these interactions may complicate or overwhelm the response of individual ecosystem 
functions to biodiversity. However, considerations of resource demand and functional spillover does provide a framework for putting BEF relationships within separate ecosystem functions and biological components into a multicomponent perspective.

\section{Conclusions}

Five important considerations were identified for the practical application of BEF relationships in monitoring (i.e. operationalization), however the information required for immediate use is currently lacking and therefore prevents wide-spread implementation of BEF-based functional monitoring. This review reported many positive and some negative relationships within many biological components, habitat and ecosystem functions. Null relationships were also reported. The consistency of the positive and negative relationships was often low which complicates universal acceptance and confident use of BEF relationships within monitoring application. Equally, some biological components and functions have received little or no investigation. Many of the biological components that potentially contribute the most to functional delivery have received the least amount of attention, for example, because of the difficulty in measuring and defining biodiversity. The benthic flora and fauna have received the greatest amount of BEF research effort and as such, there is more scope for trialling operationalized BEF-based monitoring within these systems - other habitats will probably remain dependent on direct measures of functional processes for the time being. The other significant information shortage is on the relative contribution of biotic and abiotic effects on functioning for almost all biological components and ecosystem functions. Without this information it is not possible to contextualize the influence of BEF relationships for overall functional expression. Evidence is also lacking for the value of biodiversity per se in ecosystem functional responses.

Although there are significant short-comings of the evidence for BEF relationships in many biological components and the interactions between biological components and ecosystem functions, e.g. trophic cascades and functional spill-over, the approach shows promise as a cost-effective (especially when structure measures of biodiversity are already being collected) and sensitive surrogate measure of a substantial element of ecosystem functioning. The use of BEF relationships represents the ability to examine ecosystem functions via the species-based apparatus of functional delivery, for example, the genotypes, individuals, species and assemblages of ecosystems, rather directly measure ecosystem functions. Furthermore, as long as the appropriate biological components are sampled, functional surrogates derived from 
biodiversity should be able to provide proxy information on multiple functions simultaneously unlike direct measures on single functions. Once the underlying evidence is in place, a methodology using biodiversity-based estimates of ecosystem function is likely to be costeffective and complementary to other forms of monitoring.

Furthermore, it should also be theoretically possible to combine existing information on the sensitivity of species with BEF relationships so that predictions of biodiversity-induced ecosystem functioning can be generated from realistic scenarios of species loss. This approach might be particularly informative for relationships underpinned by identity effects and hence a reduced number of highly influential species. There is also the potential for the widescale identification of species with strong identity effects for use as indicator species and functionally-relevant surrogates of total biodiversity with BEF relationships. This may reduce the need for full enumeration of the contributing biological components or initial translation of biodiversity into functional diversity units, thereby potentially reduce the cost of operationalizing BEF relationships. Although they have not been addressed in detail in this review, the shortcomings of Biological Trait Analysis to fully compensate for identity effects need to be better understood and the role performance and/or influence needs to be better represented within these tools for the translation of identity effects.

Despite the current lack of sufficient evidence to support each of the operational requirements described above, it is still possible to establish a protocol highlighting how BEF relationships might contribute within a realistic ecosystem function monitoring framework (Fig. 4). Fig. 4 suggests a process by which (1) the initial functionality requirement is divided into constituent functions, (2) biodiversity is sampled, (3) the biodiversity is expressed as comparable and functionally-relevant units, (4) biodiversity is combined with other important contributors of the rate of ecosystem function (i.e. abiotic influences), and (5) estimated ecosystem functions are recombined into overall assessments of ecosystem functionality. Although the currently available information is insufficient for implementing this protocol in practice, it constitutes a conceptual framework that will stimulate and direct future work focussing on developing operational applications for BEF relationships.

It is evident that BEF assessments are likely to be complex and the required information to operationalize them is currently lacking. Thankfully, ecosystem modelling provides a suitable approach to elevate both problems. Models are routinely used to confidently infer ecological properties (Kirwan et al., 2009; Saint-B eat et al., 2015), even in data-poor situations. For 
example, modelling tools such as Ecopath and Ecosim modelling (Coll et al., 2009) and trophic network analysis (Saint-B eat et al., 2015) are widely accepted approaches for tackling various ecological questions and have both been applied to BEF research (e.g. Arias-Gonzalez et al., 1997; Ulanowicz, 2004). Furthermore, they are particularly useful for combining numerous and diverse data sources for examining holistic or emergent properties that might not be evident from direction observation alone (Fath et al., 2007). As such, it is recommended that ecosystem modelling approaches, such as ecological network analysis, are immediately adopted within the operationalization process. This is likely to:

(1) allow the existing BEF information and assessment framework suggested here to be combined to a unified and functioning tool;

(2) provide useful 'spin-off' indicators of ecosystem function;

(3) Clearly identify the knowledge gaps, through sensitivity analysis, that impact on the overall monitoring results;

(4) potentially infer some of the missing information so that trialling of the operationalized BEF monitoring can commence; and

(5) allow the distribution of a standardized BEF assessment tool to other interested parties and member states.

Until the significant knowledge gaps described above are filled, BEF-based functional monitoring remains highly attractive yet unachievable. The greater need for the inclusion of functional considerations within wide-spread marine monitoring and assessment, (for example the MSFD), without a proportional increase in resources to deliver them, will hopefully promote BEF research and its adoption within useful practical applications. 

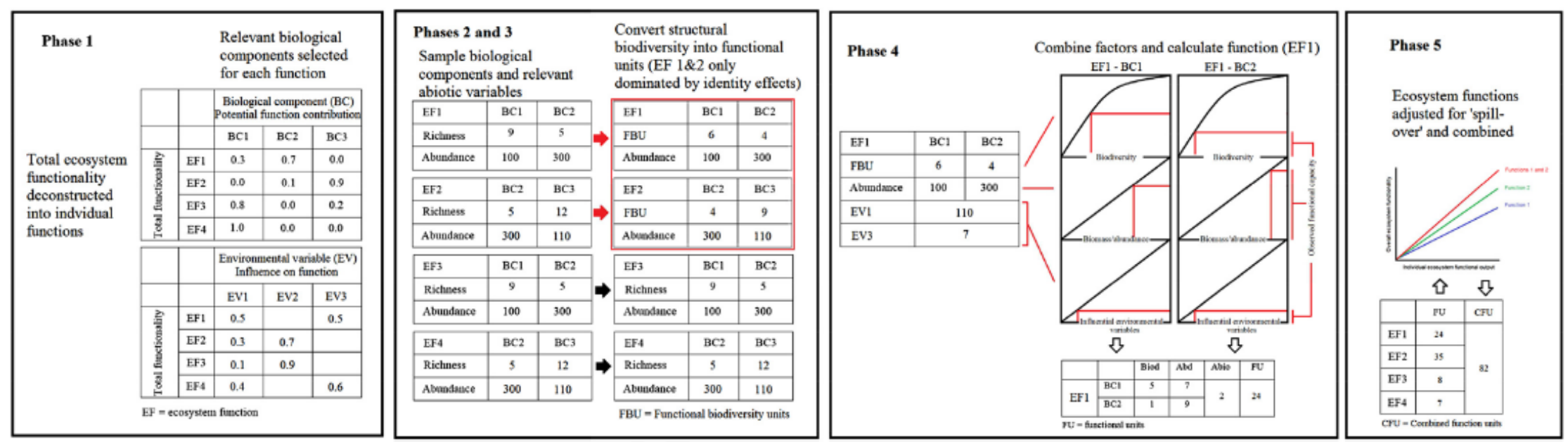

Fig. 4. Potential framework for the practical application of BEF relationships within marine ecosystem functionality monitoring. 


\section{Uncited references}

Barron et al., 2003; Duffy and Stachowicz, 2006; Emerson, 1991; Glibert et al., 2005; Higgins and Thiel, 1988; Loreau et al., 2002; Pusceddu et al., 2007; Trites, 2003

\section{Acknowledgements}

This review has resulted from the DEVOTES (DEVelopment Of innovative Tools for understanding marine biodiversity and assessing good Environmental Status) project funded by the European Union Seventh Programme for Research, Technological Development and Demonstration, 'The Ocean of Tomorrow' Theme (grant agreement no. 308392), www.devotes-project.eu.

\section{Glossary of common biodiversity and ecosystem functioning terms}

Biodiversity: The variability among living organisms from all sources including inter alia, [terrestrial], marine [and other aquatic ecosystems] and the ecological complexes of which they are part; cf. 'includes diversity within species, between species and of ecosystems' (Article 2, Convention on Biological Diversity 1992: www.cbd.int/convention/text/ default.shtml).

Biological (or biodiversity) components: groupings of species, separated by distinct functional, taxonomic and/or habitat boundaries. These components are practical subdivisions of biodiversity. Eleven biodiversity components have been used within this review: microbes, phyto-plankton, zooplankton, angiosperms, macroalgae, benthic invertebrates, fish, cephalopods, marine mammals, birds and reptiles.

Biological traits analysis: an analysis that uses a series of life history, morphological and behavioural characteristics of species present in assemblages to indicate aspects of their ecological functioning (Bremner et al., 2003).

Complementarity: see transgressive over-yielding. Species perform better in diverse communities when compared to monoculture due to facilitation and niche partitioning in shared resource use. Contributes to more efficient acquisition of limiting resources and therefore higher productivity. 
Ecosystem functioning: This relates to rate processes at the ecosystem level, cf. ecosystem structure which is the magnitude of ecosystem components at one time; all levels of biological organisation from the cell to the ecosystem have structural and functional properties whereas ecosystem functioning only relates to the highest level.

Ecosystem functions: the physical, chemical and biological processes that transform and translocate energy or materials in an ecosystem are termed ecosystem functions (Naeem, 1998; Paterson et al., 2012).

Ecosystem process:

Identity effects: a small number of species dominates functionality. Typically reflected by non-transgressive over yielding (Table $1 \mathrm{a}$ and $\mathrm{b}$ ).

Non-transgressive over-yielding: a diverse assemblage performs better than a weighted average of the component species (Table $1 \mathrm{a}$ and $\mathrm{b}$ ). Commonly related to identity effects.

Production/Productivity: biomass production is often expressed as production or productivity, these two terms being often used as synonyms (e.g. McLusky and Elliott, 2004; SchererLorenzen, 2005), and expressing the units of biomass produced per unit area per unit time (e.g. grams of Carbon m_2 yr_1 ), with the production efficiency (or biomass turnover rate) being measured by the $P: B$ ratio (where $P$ is production and $B$ is mean standing biomass; e.g. in yr_1 units; McLusky and Elliott, 2004).

Selection effects/sampling effects: diversity effects are caused by the greater chance of one or a few dominant, high-biomass species being present in the polyculture. Related to identity effects.

Trait diversity: species defined in terms of their ecological roles. The concept of functional trait diversity is based on the assumption that with increasing trait dissimilarity among species the diversity in resource use strategies increases as well and species overlap along resource axes decreases.

Transgressive over-yielding: diverse assemblages perform better than the best performing species in monoculture (Table 1a and b). Also considered a product of complementarity.

\section{References}


Allgeier, J.E., Layman, C.A., Mumby, P.J., Rosemond, A.D., 2014. Consistent nutrient storage and supply mediated by diverse fish communities in coral reef ecosystems. Glob. Change Biol. http://dx.doi.org/10.1111/gcb.12566.

Alves, A.S., Adao, H., Patrício, J., Neto, J.M., Costa, M.J., Marques, J.C., 2009. Spatial distribution of subtidal meiobenthos along estuarine gradients in two southern European estuaries (Portugal). J. Mar. Biol. Assoc. U. K. 89 (8), 1529-1540.

Arenas, F., Rey, F., Sousa Pinto, I., 2009. Diversity effects beyond species richness: evidence from intertidal macroalgal assemblages. Mar. Ecol. Prog. Ser. 381, 99-108.

Arias-Gonzalez, J.E., Delesalle, B., Salvat, B., Galzin, R., 1997. Trophic functioning of the Tiahura reef sector, Moorea Island, French Polynesia. Coral Reefs 16 (4), 231-246.

Arndt, S., Jørgensen, B.B., LaRowe, D.E., Middelburg, J.J., Pancost, R.D., Regnier, P., 2013. Quantifying the degradation of organic matter in marine sediments: a review and synthesis. Earth Sci. Rev. 123, 53-86.

Arnosti, C., 2011. Microbial extracellular enzymes and the marine carbon cycle. Annu. Rev. Mar. Sci. 3, 401-425.

Arntz, W.E., Gili, J.M., Reise, K., 1999. Unjustifiably Ignored: Reflections on the Role of Benthos in Marine Ecosystems. Springer, Dordrecht.

Arrigo, K.R., 2005. Marine microorganisms and global nutrient cycles. Nature 437, 349355.

Atkins, J.P., Burdon, D., Elliott, M., Gregory, A.J., 2011. Management of the marine environment: integrating ecosystem services and societal benefits with the DPSIR framework in a systems approach. Mar. Pollut. Bull. 62 (2), 215-226.

Balvanera, P., Pfisterer, A.B., Buchmann, N., He, J.S., Nakashizuka, T., Raffaelli, D., Schmid, B., 2006. Quantifying the evidence for biodiversity effects on ecosystem functioning and services. Ecol. Lett. 9, 1146-1156.

Barron, C., Marba, N., Duarte, C.M., Pedersen, M.F., Lindblad, C., Kersting, K., Moy, F., Bokn, T., 2003. High organic carbon export precludes eutrophication responses in experimental rocky shore communities. Ecosystems 6, 144-153. 
Barron, C., Apostolaki, E.T., Duarte, C.M., 2012. Dissolved organic carbon release by marine macrophytes. Biogeosci. Discuss. 9 (2), 1529-1555.

Biles, C.L., Solan, M., Isaksson, I., Paterson, D.M., Emes, C., Raffaelli, D.G., 2003. Flow modifies the effect of biodiversity on ecosystem functioning: an in situ study of estuarine sediments. J. Exp. Mar. Biol. Ecol. 285, 165-177.

Birchenough, S.N.R., Parker, R.E., McManus, E., Barry, J., 2012. Combining bioturbation and redox metrics: potential tools for assessing seabed function. Ecol. Indic. 12 (1), 816.

Bolam, S.G., Fernandes, T.F., Huxham, M., 2002. Diversity, biomass, and ecosystem processes in the marine benthos. Ecol. Monogr. 72 (4), 599-615.

Borer, E.T., Seabloom, E.W., Shurin, J.B., Anderson, K.E., Blanchette, C.A., Broitman, B., Cooper, S.D., Halpern, B.S., 2005. What determines the strength of a trophic cascade? Ecology 86 (2), 528-537.

Boudouresque, C.F., Bernard, G., Bonhomme, P., Charbonnel, E., Diviacco, G., Meinesz, A., Pergent, G., Pergent-martini, C., Ruitton, S., Tunesi, L., 2012. Protection and Conservation of Posidonia Oceanica Meadows. RAMOGE and RAC/ SPA Publ., Tunis, pp. 1-202.

Boyer, K.E., Kertesz, J.S., Bruno, J.F., 2009. Biodiversity effects on productivity and stability of marine macroalgal communities: the role of environmental context. Oikos 118 (7), 1062-1072.

Boyle, P., 2002. Cephalopod biomass and production: an introduction to the symposium. Bull. Mar. Sci. 71, 13-16.

Bracken, M.E., Stachowicz, J.J., 2006. Seaweed diversity enhances nitrogen uptake via complementary use of nitrate and ammonium. Ecology 87 (9), 2397-2403.

Bracken, M.E., Williams, S.L., 2013. Realistic changes in seaweed biodiversity affect multiple ecosystem functions on a rocky shore. Ecology 94 (9), 1944-1954.

Bremner, J., 2008. Species traits and ecological functioning in marine conservation and management. J. Mar. Biol. Ecol. 366, 37-47. 
Bremner, J., Rogers, S.I., Frid, C.L.J., 2003. Assessing functional diversity in marine benthic ecosystems: a comparison of approaches. Mar. Ecol. Prog. Ser. 254, 11-25.

Bruno, J.F., Boyer, K.E., Duffy, J.E., Lee, S.C., Kertesz, J.S., 2005. Effects of macroalgal species identity and richness on primary production in benthic marine communities. Ecol. Lett. 8 (11), 1165-1174.

Bulling, M.T., Hicks, N., Murray, L., Paterson, D.M., Raffaelli, D., White, P.C., Solan, M., 2010. Marine biodiversity-ecosystem functions under uncertain environmental futures. Philos. Trans. Roy. Soc. B: Biol. Sci. 365 (1549), 2107-2116.

Canuel, E.A., Spivak, A.C., Waterson, E.J., Duffy, J., 2007. Biodiversity and food web structure influence short-term accumulation of sediment organic matter in an experimental seagrass system. Limnol. Oceanogr. 52 (2), 590-602.

Caporaso, J.G., Kuczynski, J., Stombaugh, J., Bittinger, K., Bushman, F.D., Costello, E.K., Knight, R., 2010. QIIME allows analysis of high-throughput community sequencing data. Nat. Methods 7 (5), 335-336.

Cardinale, B.J., Srivastava, D.S., Duffy, J.E., Wright, J.P., Downing, A.L., Sankaran, M., Jouseau, C., 2006. Effects of biodiversity on the functioning of trophic groups and ecosystems. Nature 443, 989-992.

Cardinale, B.J., Wright, J.P., Cadotte, M.W., Carroll, I.T., Hector, A., Srivastava, D.S., Loreau, M., Weis, J.J., 2007. Impacts of plant diversity on biomass production increase through time because of species complementarity. Proc. Natl. Acad. Sci. U. S. A. 104, 18123-18128.

Cardinale, B.J., Duffy, J.E., Gonzalez, A., Hooper, D.U., Perrings, C., Venail, P., Narwani, A., MacE, G.M., Tilman, D., Wardle, D.A., Kinzig, A.P., Daily, G.C., Loreau, M., Grace, J.B., Larigauderie, A., Srivastava, D.S., Naeem, S., 2012. Biodiversity loss and its impact on humanity. Nature 486, 59-67.

Carpenter, E.J., 1983. Nitrogen fixation by marine Oscillatoria (Trichodesmium) in the world's oceans. In: Carpenter, E.J., Capone, D.G. (Eds.), Nitrogen in the Marine Environment. Academic Press, New York, pp. 65-103.

Cebrian, J., 2002. Variability and control of carbon consumption, export, and accumulation in 
marine communities. Limnol. Oceanogr. 47 (1), 11-22.

Chapin, F.S., Walker, B.H., Hobbs, R.J., Hooper, D.U., Lawton, J.H., Sala, O.E., Tilman, D., 1997. Biotic control over the functioning of ecosystems. Science 277 (5325), 500-504.

Chapman, B.B., Hulthén, K., Brodersen, J., Nilsson, P.A., Skov, C., Hansson, L.A., Bronmark, C., 2012. Partial migration in fishes: causes and consequences. J. Fish Biol. 81 (2), 456-478.

Cho, B.C., Azam, F., 1988. Major role of bacteria in biogeochemical fluxes in the ocean's interior. Nature 332, 441-443.

Christensen, V., Pauly, D. (Eds.), 1993. Trophic Models of Aquatic Ecosystems, vol. 26. WorldFish.

Clarke, M.R., 1996. Cephalopods as prey III. Cetaceans. Philos. Trans. Roy. Soc. Lond. B 351, 1053-1065.

Coll, M., Bundy, A., Shannon, L.J., 2009. Ecosystem modelling using the Ecopath with Ecosim approach. In: Computers in Fisheries Research. Springer, Netherlands, pp. 225291.

Covich, A.P., Austen, M.C., Bärlocher, F., Chauvet, E., Cardinale, B.J., Biles, C.L., Inchausti, P., Dangles, O., Solan, M., Gessner, M.O., Statzner, B., Moss, B., 2004. The role of biodiversity in the functioning of freshwater and Marine benthic ecosystems. BioScience 54 (8), 767-775.

Cury, P., Shannon, L., Shin, Y.J., 2003. The functioning of marine ecosystems: a fisheries perspective. In: Sinclair, M., Valdimarsson, G. (Eds.), Responsible Fisheries in the Marine Ecosystem. FAO/CAB International, Rome, Italy/Wallingford, UK, p. 103.

Dale, A.W., Prego, R., 2002. Physico-biogeochemical controls on benthic-pelagic coupling of nutrient fluxes and recycling in a coastal upwelling system. Mar. Ecol. Prog. Ser. 235, 1528.

Danovaro, R., Pusceddu, A., 2007. Biodiversity and ecosystem functioning in coastal lagoons: does microbial diversity play any role? Estuar. Coast. Shelf Sci. 75 (1), 4-12.

Danovaro, R., Corinaldesi, C., Filippini, M., Fischer, U.R., Gessner, M.R., Jaqchet, S., 
Magagnini, M., Velimirov, B., 2008a. Viriobenthos in freshwater and marine sediments: a review. Freshw. Biol. 53, 1186-1213.

Danovaro, R., Gambi, C., Dell'Anno, A., Corinaldesi, C., Fraschetti, S., Vanreusel, A., Vincx, M., Gooday, A.J., 2008b. Exponential decline of deep-sea ecosystem functioning linked to benthic biodiversity loss. Curr. Biol. 18, 1-8.

Davies, T.W., Jenkins, S.R., Kingham, R., Kenworthy, J., Hawkins, S.J., Hiddink, J.G., 2011. Dominance, biomass and extinction resistance determine the consequences of biodiversity loss for multiple coastal ecosystem processes. PLoS ONE 6 (12), e28362.

del Giorgio, P.A., Cole, J.J., 1998. Bacterial growth efficiency in natural aquatic systems. Annu. Rev. Ecol. Syst. 29, 503-541.

Di Poi, E., Blason, C., Corinaldesi, C., Danovaro, R., Malisana, E., Fonda-Umani, S., 2013. Structure and interactions within the pelagic microbial food web (from viruses to microplankton) across environmental gradients in the Mediterranean Sea. Glob. Biogeochem. Cycles 27 (4), 1034-1045.

Dornelas, M., Gotelli, N.J., McGill, B., Shimadzu, H., Moyes, F., Sievers, C., Magurran, A.E., 2014. Assemblage time series reveal biodiversity change but not systematic loss. Science 344, 296-299.

Duffy, J.E., Harvilicz, A.M., 2001. Species-specific impacts of grazing amphipods in an eelgrass-bed community. Mar. Ecol. Prog. Ser. 223, 201-211.

Duffy, J.E., Stachowicz, J.J., 2006. Why biodiversity is important to oceanography: potential roles of genetic, species, and trophic diversity in pelagic ecosystem processes. Mar. Ecol. Prog. Ser. 311, 179-189.

Duffy, E., Richardson, P.J., Canuel, E.A., 2003. Grazer diversity effects on ecosystem functioning in seagrass beds. Ecol. Lett. 6 (7), 637-645.

Duffy, E., Richardson, P.J., France, K.E., 2005. Ecosystem consequences of diversity depend on food chain length in estuarine vegetation. Ecol. Lett. 8 (3), 301-309.

Edwards, K.F., Aquilino, K.M., Best, R.J., Sellheim, K.L., Stachowicz, J.J., 2010. Prey diversity is associated with weaker consumer effects in a meta-analysis of benthic marine experiments. Ecol. Lett. 13 (2), 194-201. 
Ehlers, A., Worm, B., Reusch, T.B., 2008. Importance of genetic diversity in eelgrass Zostera marina for its resilience to global warming. Mar. Ecol. Prog. Ser. 355, 1-7.

Emerson, C.W., 1991. A method for the measurement of bedload sediment transport and passive faunal transport on intertidal sandflats. Estuaries 14 (4), 361-371.

Emmerson, M.C., Raffaelli, D.G., 2000. Detecting the effects of diversity on measures of ecosystem function: experimental design, null models and empirical observations. Oikos 195-203.

Emmerson, M.C., Solan, M., Emes, C., Paterson, D.M., Raffaelli, D., 2001. Consistent patterns and the idiosyncratic effects of biodiversity in marine ecosystems. Nature 411 (6833), 73-77.

Epifanio, C.E., Dittel, A.I., Rodriquez, R.A., Targett, T.E., 2003. The role of macroalgal beds as nursery habitat for juvenile blue crabs, Callinectes sapidus. J. Shellfish Res. 22, 881 886.

Falkowski, P.G., Barber, R.T., Smetacek, V., 1998. Biogeochemical controls and feedbacks on ocean primary production. Science 281, 200-206.

Fath, B.D., Scharler, U.M., Ulanowicz, R.E., Hannon, B., 2007. Ecological network analysis: network construction. Ecol. Model. 208 (1), 49-55.

Field, C.B., Behrenfeld, M.J., Randerson, J.T., Falkowski, P., 1998. Primary production of the biosphere: integrating terrestrial and oceanic components. Science 281 (5374), $237-$ 240.

Finke, D.L., Denno, R.F., 2004. Predator diversity dampens trophic cascades. Nature 429 (6990), 407-410.

Fowler, S.W., Knauer, G.A., 1986. Role of large particles in the transport of elements and organic-compounds through the oceanic water column. Prog. Oceanogr. 16 (3), 147-194.

France, K.E., Duffy, J.E., 2006. Diversity and dispersal interactively affect predictability of ecosystem function. Nature 441 (7097), 1139-1143.

France, R., Chandler, M., Peters, R., 1998. Mapping trophic continua of benthic food-webs: body size-15N relationships. Mar. Ecol. Prog. Ser. 174, 301-306. 
Gamfeldt, L., Lefcheck, J.S., Byrnes, J.E.K., Cardinale, B.J., Duffy, J.E., Griffin, J.N., 2014. Marine biodiversity and ecosystem functioning: what's known and what's next? PeerJ Prepr. 2, e249v1. http://dx.doi.org/10.7287/peeri.preprints.249v1.

Gasol, J.M., del Giorgio, P.A., Duarte, C.M., 1997. Biomass distribution in marine planktonic communities. Limnol. Oceanogr. 42 (6), 1353-1363.

Giere, O., 2009. Meiobenthology: the Microscopic Motile Fauna of Aquatic Sediments, second ed. Springer, Berlin.

Gilbert, F., Stora, G., Bonin, P., 1998. Influence of bioturbation on denitrification activity in Mediterranean coastal sediments: an in situ experimental approach. Mar. Ecol. Prog. Ser. 163, 99-107.

Gilbertson, W.W., Solan, M., Prosser, J.I., 2012. Differential effects of microorganisminvertebrate interactions on benthic nitrogen cycling. FEMS Microbiol. Ecol. 82 (1), 11-22.

Giles, H., Pilditch, C.A., 2006. Effects of mussel (Perna canaliculus) biodeposit decomposition on benthic respiration and nutrient fluxes. Mar. Biol. 150 (2), 261-271.

Giller, P., Hillebrand, H., Berninger, U.G., Gessner, M.O., Hawkins, S., Inchausti, P., Inglis, C., Leslie, H., Malmqvist, B., Monaghan, M.T., Morin, P.J., O'Mullan, G., 2004. Biodiversity effects on ecosystem functioning: emerging issues and their experimental test in aquatic environments. Oikos 104 (3), 423-436.

Gingold, R., Moens, T., Rocha-Olivares, A., 2013. Assessing the response of nematode communities to climate change-driven warming: a microcosm experiment. PLoS ONE 8, e66653.

Giovannoni, S.J., Stingl, U., 2005. Molecular diversity and ecology of microbial plankton. Nature 437, 343-348.

Glibert, P.M., Anderson, D.M., Gentien, P., Granéli, E., Sellner, K.G., 2005. The global, complex phenomena of harmful algal blooms. Oceanography 18 (2), 136-147.

Gobet, A., Boeer, S.I., Huse, S.M., van Beusekom, J.J.E., Quince, C., Sogin, M.L., Boetius, A., Ramette, A., 2012. Diversity and dynamics of rare and of resident bacterial populations in coastal sands. ISME J. 6, 542-553. 
Godbold, J.A., 2012. Effects of biodiversity-environment conditions on the interpretation of biodiversity-function relations. Mar. Biodivers. Ecosyst. Funct. Fram. Methodol. Integr. 101.

Godbold, J.A., Solan, M., 2009. Relative importance of biodiversity and the abiotic environment in mediating an ecosystem process. Mar. Ecol. Prog. Ser. 396, 273-282.

Godbold, J.A., Solan, M., Killham, K., 2009. Consumer and resource diversity effects on marine macroalgal decomposition. Oikos 118, 77-86.

Goebel, N.L., Edwards, C.A., Follows, M.J., Zehr, J.P., 2014. Modeled diversity effects on microbial ecosystem functions of primary production, nutrient uptake, and remineralization. Ecology 95, 153-163.

Gray, J.S., Elliott, M., 2009. Ecology of Marine Sediments: from Science to Management. Oxford University Press.

Griffin, J.N., Méndez, V., Johnson, A.F., Jenkins, S.R., Foggo, A., 2009. Functional diversity predicts overyielding effect of species combination on primary productivity. Oikos 118 (1), 37-44.

Gruber, N., Sarmiento, J.L., 1997. Global patterns of marine nitrogen fixation and denitrification. Glob. Biogeochem. Cycles 11, 235-266.

Gude, H., 1988. Direct and indirect influences of crustacean zooplankton on bacterioplankton of Lake Constance. Hydrobiologia 159, 63-73.

Gustafsson, C., Bostrbm, C., 2011. Biodiversity influences ecosystem functioning in aquatic angiosperm communities. Oikos 120, 1037-1046.

Gutiérrez, J.L., Jones, C.G., Byers, J.E., Arkema, K.K., Berkenbusch, K., Commito, J.A., Duarte, C.M., et al., 2011. Physical ecosystem engineers and the functioning of estuaries and coasts. In: Heip, C.H.R., Philippart, C.J.M., Middelburg, J.J. (Eds.), Functioning of Estuaries and Coastal Ecosystems. Elsevier, Amsterdam.

Harrold, C., Light, K., Lisin, S., 1998. Organic enrichment of submarine-canyon and continental-shelf benthic communities by macroalgal drift imported from nearshore kelp forests. Limnol. Oceanogr. 43, 669-678. 
Harvey, E., SéGuin, A., Nozais, C., Archambault, P., Gravel, D., 2013. Identity effects dominate the impacts of multiple species extinctions on the functioning of complex food webs. Ecology 94 (1), 169-179.

Hastie, L.C., Pierce, G.J., Wang, J., Bruno, I., Moreno, A., Piatkowski, U., Robin, J.P., 2009. Cephalopods in the north-eastern Atlantic: species, biogeography, ecology, exploitation and conservation. Oceanogr. Mar. Biol.: Annu. Rev. 47, 111-190.

Hector, A., Joshi, J., Scherer-Lorenzen, M., Schmid, B., Spehn, E.M., Wacker, L., Weilenmann, M., Bazeley-White, E., Beierkuhnlein, C., Caldeira, M.C., Dimitrakopoulos, P.G., Finn, J.A., Huss-Danell, K., Jumpponen, A., Leadley, P.W., Loreau, M., Mulder, C.P.H., Nesshoover, C., Palmborg, C., Read, D.J., Siamantziouras, A.S.D., Terry, A.C., Troumbis, A.Y., 2007. Biodiversity and ecosystem functioning: reconciling the results of experimental and observational studies. Funct. Ecol. 21, 998-1002.

Hensel, M.J., Silliman, B.R., 2013. Consumer diversity across kingdoms supports multiple functions in a coastal ecosystem. Proc. Natl. Acad. Sci. U. S. A. 110 (51), 20621-20626.

Higgins, R.P., Thiel, H., 1988. Introduction to the Study of Meiofauna. Smithsonian Institution Press, Washington, DC, London, p. 488.

Hillebrand, H., Cardinale, B.J., 2004. Consumer effects decline with prey diversity. Ecol. Lett. 7, 192-201.

Hooper, D.U., Adair, E.C., Cardinale, B.J., Byrnes, J.E., Hungate, B.A., Matulich, Gonzalez, A., Duffy, J.E., Gamfeldt, L., O'Connor, M.I., 2012. A global synthesis reveals biodiversity loss as a major driver of ecosystem change. Nature 486 (7401), 105-108.

Hughes, A.R., Stachowicz, J.J., 2004. Genetic diversity enhances the resistance of a seagrass ecosystem to disturbance. Proc. Natl. Acad. Sci. U. S. A. 101 (24), 8998-9002.

Hughes, A.R., Stachowicz, J.J., 2009. Ecological impacts of genotypic diversity in the clonal seagrass Zostera marina. Ecology 90 (5), 1412-1419.

Hughes, A.R., Best, R.J., Stachowicz, J.J., 2010. Genotypic diversity and grazer identity interactively influence seagrass and grazer biomass. Mar. Ecol. Prog. Ser. 403, 43-51.

Hull, S.C., 1987. Macroalgal mats and species abundance: a field experiment. Estuar. Coast. Shelf Sci. 25, 519-532. 
Hunsicker, M.E., Essington, T.E., 2008. Evaluating the potential for trophodynamic control of fish by the longfin inshore squid (Loligo pealeii) in the Northwest Atlantic Ocean. Can. J. Fish. Aquat. Sci. 65, 2524-2535.

leno, E.N., Solan, M., Batty, P., Pierce, G.J., 2006. How biodiversity affects ecosystem functioning: roles of infaunal species richness, identity and density in the marine benthos. Mar. Ecol. Prog. Ser. 311, 263-271.

Ikeda, T., 1985. Metabolic rates of epipelagic marine zooplankton as a function of body mass and temperature. Mar. Biol. 85, 1-11.

Infantes, E., Orfila, A., Simarro, G., Terrados, J., Luhar, M., Nepf, H., 2012. Effect of a seagrass (Posidonia oceanica) meadow on wave propagation. Mar. Ecol. Prog. Ser. 456, 63-72.

Irigoien, X., Huisman, J., Harris, R.P., 2004. Global biodiversity patterns of marine phytoplankton and zooplankton. Nature 429, 863-867.

Jackson, E.I, Griffiths, C.A., Durkin, O., 2013. A Guide to Assessing and Managing Anthropogenic Impact on Marine Angiosperm Habitat - Part 1: Literature Review. Natural England Commissioned Reports, Number 111. MAIA Marine Protected areas in the Atlantic Arc report.

Janson, A., Denis, L., Rauch, M., Desroy, N., 2012. Macrobenthic biodiversity and oxygen uptake in estuarine systems: the example of the Seine estuary. J. Soils Sedim. 12, 15681580.

Jenkins, S.R., Hawkins, S.J., Norton, T.A., 1999. Direct and indirect effects of a macroalgal canopy and limpet grazing in structuring a sheltered inter-tidal community. Mar. Ecol. Prog. Ser. 188, 81-92.

Jennings, S., Nicholson, M.D., Dinmore, T.A., Lancaster, J., 2002. The effect of chronic trawling disturbance on the production of infaunal communities. Mar. Ecol. Prog. Ser. 243, 251-260.

Johnson, C.L., Runge, J.A., Curtis, K.A., Durbin, E.G., Hare, J.A., Incze, L.S., Link, J.S., Melvin, G.D., O'Brien, T.D., Guelpen, L.V., 2011. Biodiversity and ecosystem function in the Gulf of Maine: pattern and role of zooplankton and pelagic nekton. PLoS ONE 6, 
e16491.

Jones, C.G., Lawton, J.H., Shachak, M., 1994. Organisms as ecosystem engineers. Oikos 69, 373-386.

Jordan, M.A., Welsh, D.T., Dunn, R.J., Teasdale, P.R., 2009. Influence of Trypaea australiensis population density on benthic metabolism and nitrogen dynamics in sandy estuarine sediment: a mesocosm simulation. J. Sea Res. 61 (3), 144-152.

Jørgensen, B.B., Revsbech, N.P., 1989. Oxygen uptake, bacterial distribution, and carbonnitrogen-sulfur cycling in sediments from the Baltic Sea-North Sea transition. Ophelia 31 (1), 29-49.

Karlson, A.M., Nascimento, F.J., Naslund, J., Elmgren, R., 2010. Higher diversity of depositfeeding macrofauna enhances phytodetritus processing. Ecology 91 (5), 1414-1423.

Kennedy, H., Björk, M., 2009. Seagrasses. In: Laffoley, D., Grimsditch, G. (Eds.), The Management of Natural Coastal Carbon Sinks in Coastal Ecosystems: Investigating and Realising the Potential. IUCN, Gland, Switzerland, pp. 23-30.

Kiørboe, T., 2000. Colonization of marine snow aggregates by invertebrate zooplankton: abundance, scaling and possible role. Limnol. Oceanogr. 45, 479-484.

Kirwan, L., Connolly, J., Finn, J.A., Brophy, C., Lüscher, A., Nyfeler, D., Sebastia, M.T., 2009. Diversity-interaction modeling: estimating contributions of species identities and interactions to ecosystem function. Ecology 90 (8), 2032-2038. Kleiber, M., 1947. Body size and metabolic rate. Physiol. Rev. 27, 511-541.

Kochmann, J., Buschbaum, C., Volkenborn, N., Reise, K., 2008. Shift from native mussels to alien oysters: differential effects of ecosystem engineers. J. Exp. Mar. Biol. Ecol. 364 (1), $1-10$

Kraufvelin, P., Lindholm, A., Pedersen, M.F., Kirkerud, L.A., Bonsdorff, E., 2010. Biomass, diversity and production of rocky shore macroalgae at two nutrient enrichment and wave action levels. Mar. Biol. 157 (1), 29-47.

Kristensen, E., 2001. Impact of polychaetes (Nereis spp. and Arenicola marina) on carbon biogeochemistry in coastal marine sediments. Geochem. Trans. 2, 92-103. 
Kristiansen, J., 1990. Phylum Chrysophyta. In: Margulis, L., Corliss, J.O., Melkonian, M., Chapman, D.J. (Eds.), Handbook of Protoctista. Jones and Bartlett, Boston, MA, USA, pp. 438-453.

Lampert, W., 1978. Release of dissolved organic carbon by grazing zooplankton. Limnol. Oceanogr. 23, 831-834.

Lanari, M.D.O., Coutinho, R., 2014. Reciprocal causality between marine macroalgal diversity and productivity in an upwelling area. Oikos 123 (5), 630-640.

Langenheder, S., Bulling, M.T., Solan, M., Prosser, J.I., 2010. Bacterial biodiversityecosystem functioning relations are modified by environmental complexity. PLoS ONE 5 (5), e10834.

Laws, E.A., 1991. Photosynthetic quotients, new production and net community production in the open ocean. Deep Sea Res. Part A. Oceanogr. Res. Papers 38 (1), 143-167.

Layman, C.A., Winemiller, K.O., Arrington, D.A., Jepsen, D.B., 2005. Body size and trophic position in a diverse tropical food web. Ecology 86 (9), 2530-2535.

Leduc, D., Rowden, A.A., Pilditch, C.A., Maas, E.W., Probert, P.K., 2013. Is there a link between deep-sea biodiversity and ecosystem function? Mar. Ecol. 34, 334-344.

Lewitus, A.J., Caron, D.A., 1991. Physiological responses of phytoflagellates to dissolved organic substrate additions. 1. Dominant role of heterotrophic nutrition in Poterioochromonas malhamensis (Chrysophyceae). Plant Cell Physiol. 32, 671-680.

Liu, Z., Kobiela, M., McKee, G., Tang, T., Lee, C., Mulholland, M., Hatcher, P., 2010. The effect of chemical structure on the hydrolysis of tetrapeptides in seawater: AVFA and SWGA. Mar. Chem. 119, 108-120.

Lloyd, K.G., Schreiber, L., Petersen, D.G., Kjeldsen, K.U., Lever, M.A., Steen, A., Stepanauskas, R., Richter, M., Kleindienst, S., Lenk, S., Schramm, A., Jørgensen, B.B., 2013. Predominant archaea in marine sediments degrade detrital proteins. Nature 496 , 215-218.

Lohrer, A.M., Thrush, S.F., Gibbs, M.M., 2004. Bioturbators enhance ecosystem function through complex biogeochemical interactions. Nature 431, 1092-1095. 
Longhurst, A., Sathyendranath, S., Platt, T., Caverhill, C., 1995. An estimate of global primary production in the ocean from satellite radiometer data. J. Plankton Res. 17 (6), 1245-1271.

Loreau, M., Hector, A., 2001. Partitioning selection and complementarity in biodiversity experiments. Nature 413, 548.

Loreau, M., Naeem, S., Inchausti, P., Bengtsson, J., Grime, J.P., Hector, A., Hooper, D.U., Huston, M.A., Raffaelli, D., Schmid, B., Tilman, D., Wardle, D.A., 2001. Biodiversity and ecosystem functioning: current knowledge and future challenges. Science 294 (5543), 804-808.

Loreau, M., Naeem, S., Inchausti, P., 2002. Biodiversity and Ecosystem Functioning: Synthesis and Perspectives. Oxford University Press.

Marafión, E., Holligan, P.M., Barciela, R., Gonzalez, N., Mouriño, B., Paz o, M.J., Varela, M., 2001. Patterns of phytoplankton size structure and productivity in contrasting open-ocean environments. Mar. Ecol. Prog. Ser. 216 (216), 43-56.

McIntyre, P.B., Jones, L.E., Flecker, A.S., Vanni, M.J., 2007. Fish extinctions alter nutrient recycling in tropical freshwaters. Proc. Natl. Acad. Sci. U. S. A. 104, 4461-4466.

McLusky, D., Elliott, M., 2004. The Estuarine Ecosystem: Ecology, Threats and Management, third ed. Oxford University Press, UK, p. 214.

Mermillod-Blondin, F., 2011. The functional significance of bioturbation and biodeposition on biogeochemical processes at the water-sediment interface in freshwater and marine ecosystems. J. North Am. Benthol. Soc. 30 (3), 770-778.

Middelburg, J.J., 2011. Chemoautotrophy in the ocean. Geophys. Res. Lett. 38, L24604.

Miligan, T., Hill, P., 1998. A laboratory assessment of the relative importance of turbulence, particle composition and concentration in limiting maximal floe size and settling behaviour. J. Sea Res. 39, 227-241.

Molari, M., Manini, E., Dell'Anno, A., 2013. Dark inorganic carbon fixation sustains the functioning of benthic deep-sea ecosystems. Glob. Biogeochem. Cycles 27, 212-221.

Montserrat, F., Van Colen, C., Provoost, P., Milla, M., Ponti, M., Van Den Meersche, K., 
Ysebaertb, T., Herman, P.M., 2009. Sediment segregation by biodiffusing bivalves. Estuar. Coast. Shelf Sci. 83 (4), 379-391.

Mouillot, D., Villéger, S., Scherer-Lorenzen, M., Mason, N.W., 2011. Functional structure of biological communities predicts ecosystem multifunctionality. PLoS ONE 6 (3), e17476.

Mulholland, M.R., Lee, C., 2009. Peptide hydrolysis and the uptake of dipeptides by phytoplankton. Limnol. Oceanogr. 54 (3), 856-868.

Muraoka, D., 2004. Seaweed resources as a source of carbon fixation. Bull. Fish. Res. Agency (Suppl. 1), 59-63.

Naeem, S., 1998. Species redundancy and ecosystem reliability. Conserv. Biol. 12 (1), 3945.

Naeem, S., Wright, J.P., 2003. Disentangling biodiversity effects on ecosystem functioning: deriving solutions to a seemingly insurmountable problem. Ecol. Lett. 6 (6), 567-579.

Naeem, S., Bunker, D.E., Hector, A., Loreau, M., Perrings, C., 2009. Biodiversity, ecosystem functioning, and human wellbeing. Ecol. Econ. Perspect.

Naldi, M., Wheeler, P.A., 1999. Changes in nitrogen pools in Ulva fenestrata (Chlorophyta) and Gracilaria pacifica (Rhodophyta) under nitrate and ammonium enrichment. J. Phycol. 35 (1), 70-77.

Newell, R., 2004. Ecosystem influences of natural and cultivated populations of suspensionfeeding bivalve molluscs: a review. J. Shellfish Res. 23 (1), 51-62. Norling, K., Rosenberg, R., Hulth, S., Grémare, A., Bonsdorff, E., 2007. Importance of functional biodiversity and species-specific traits of benthic fauna for ecosystem functions in marine sediment. Mar. Ecol. Prog. Ser. 332, 11-23. O'Dor, R.K., 1992. Big squid in big currents. South Afr. J. Mar. Sci. 12 (1), 225-235.

Odum, E.P., Odum, H.T., Andrews, J., 1971. Fundamentals of Ecology, vol. 3. Saunders, Philadelphia.

O'Connor, M.I., Bruno, J.F., 2009. Predator richness has no effect in a diverse marine food web. J. Anim. Ecol. 78 (4), 732-740.

O'Gorman, E.J., Enright, R.A., Emmerson, M.C., 2008. Predator diversity enhances 
secondary production and decreases the likelihood of trophic cascades. Oecologia 158 (3), 557-567.

Pandolfi, J.M., Lovelock, C.E., 2014. Novelty trumps loss in global biodiversity. Science 344, 266-267.

Paterson, D.M., Defew, E.C., Jabour, J., 2012. Ecosystem function and co-evolution of terminology in marine science and management. In: Solan, M., Aspden, R.J., Paterson, D.M. (Eds.), Marine Biodiversity and Ecosystem Functioning, vol. 1. Oxford University Press, pp. 1-240.

Pimm, S.L., Russell, G.J., Gittleman, J.L., Brooks, T.M., 1995. The future of biodiversity. Science 269 (5222), 347-350.

Pischedda, L., Poggiale, J.C., Cuny, P., Gilbert, F., 2008. Imaging oxygen distribution in marine sediments. The importance of bioturbation and sediment heterogeneity. Acta Biotheor. 56 (1-2), 123-135.

Power, L.D., Cardinale, B.J., 2009. Species richness enhances both algal biomass and rates of oxygen production in aquatic microcosms. Oikos 118 (11), 1703-1711.

Ptacnik, R., Solimini, A.G., Andersen, T., Tamminen, T., Brettum, P., Lepistb, L., Willen, E., Rekolainen, S., 2008. Diversity predicts stability and resource use efficiency in natural phytoplankton communities. Proc. Natl. Acad. Sci. U. S. A. 105, 5134-5138.

Pusceddu, A., Gambi, C., Manini, E., Danovaro, R., 2007. Trophic state, ecosystem efficiency and biodiversity of transitional aquatic ecosystems: analysis of environmental quality based on different benthic indicators. Chem. Ecol. 23, 505-515.

Pusceddu, A., Gambi, C., Corinaldesi, C., Scopa, M., Danovaro, R., 2014. Relationships between meiofaunal biodiversity and prokaryotic heterotrophic production in different tropical habitats and oceanic regions. PLoS ONE 9 (3), e91056.

Queir6s, A.M., Hiddink, J.G., Johnson, G., Cabral, H.N., Kaiser, M.J., 2011. Context dependence of marine ecosystem engineer invasion impacts on benthic ecosystem functioning. Biol. Invasions 13, 1059-1075.

Rabaut, M., Guilini, K., Van Hoey, G., Vincx, M., Degraer, S., 2007. A bio-engineered softbottom environment: the impact of Lanice conchilega on the benthic species-specific 
densities and community structure. Estuar. Coast. Shelf Sci. 75 (4), 525-536.

Rasmussen, H., Jørgensen, B.B., 1992. Microelectrode studies of seasonal oxygen uptake in a coastal sediment: role of molecular diffusion. Mar. Ecol. Prog. Ser. 81, 289303.

Reiss, J., Bridle, J.R., Montoya, J.M., Woodward, G., 2009. Emerging horizons in biodiversity and ecosystem functioning research. Trends Ecol. Evol. 24 (9), 505-514.

Reusch, T.B., Ehlers, A., Hammerli, A., Worm, B., 2005. Ecosystem recovery after climatic extremes enhanced by genotypic diversity. Proc. Natl. Acad. Sci. U. S. A. 102 (8), 28262831.

Reynolds, P.L., Bruno, J.F., 2012. Effects of trophic skewing of species richness on ecosystem functioning in a diverse marine community. PLoS ONE 7 (5), e36196.

Rigolet, C., Dubois, S.F., Thiebaut, E., 2014. Benthic control freaks: effects of the tubiculous amphipod Haploops nirae on the specific diversity and functional structure of benthic communities. J. Sea Res. 85, 413-427.

Rilov, G., Mant, R., Lyons, D., Bulleri, F., Benedetti-Cecchi, L., Kotta, J., Queir6s, A.M., Chatzinikolaou, E., Crowe, T., Guy-Haim, T., 2012. How strong is the effect of invasive ecosystem engineers on the distribution patterns of local species, the local and regional biodiversity and ecosystem functions. Environ. Evid. 1 (10).

Roesch, L.F., Fulthorpe, R.R., Riva, A., Casella, G., Hadwin, A.K., Kent, A.D., Daroub, S.H., Camargo, F.A., Farmerie, W.G., Triplett, E.W., 2007. Pyrosequencing enumerates and contrasts soil microbial diversity. ISME J. 1 (4), 283-290.

Romanuk, T.N., Hayward, A., Hutchings, J.A., 2011. Trophic level scales positively with body size in fishes. Glob. Ecol. Biogeogr. 20 (2), 231-240.

Rosenberg, G., Littler, D.S., Littler, M.M., Oliveira, E.C., 1995. Primary production and photosynthetic quotients of seaweeds from Sao Paulo State, Brazil. Bot. Mar. 38, 369377.

Saint-Beat, B., Baird, D., Asmus, H., Asmus, R., Bacher, C., Pacella, S.R., Johnson, G.A., David, V., Vezina, A.F., Niquil, N., 2015. Trophic networks: how do theories link ecosystem structure and functioning to stability properties? A review. Ecol. Indic. 52, 
458-471.

Scherer-Lorenzen, M., 2005. Biodiversity and ecosystem functioning: basic principles. In: Barthlott, W., Linsenmair, K.E., Porembski, S. (Eds.), Biodiversity: Structure and Function. Encyclopedia of Life Support Systems (EOLSS). UNESCO, Eolss Publishers, Oxford, UK.

Short, F.T., McRoy, C.P., 1984. Nitrogen uptake by leaves and roots of the seagrass Zostera marina L. Bot. Mar. 27 (12), 547-556.

Siegenthaler, U., Sarmiento, J.L., 1993. Atmospheric carbon dioxide and the ocean. Nature 365, 119-125.

Smale, M.J., 1996. Cephalopods as prey. IV. Fishes. Philos. Trans. Roy. Soc. Lond. Ser. B 351, 1067-1081.

Smith, D., Simon, M., Alldredge, A., Azam, F.,1992. Intensive hydrolytic activity on marine aggregates and implications for rapid particle dissolution. Nature 359,139-141.

Snelgrove, P.V.R., 1999. Getting to the bottom of marine biodiversity: sedimentary habitats: ocean bottoms are the most widespread habitat on earth and support high biodiversity and key ecosystem services. BioScience 49 (2), 129-138.

Snelgrove, P.V.R., Thrush, S.F., Wall, D.H., Norkko, A., 2014. Real world biodiversityecosystem functioning: a seafloor perspective. Trends Ecol. Evol. 29, 398-405.

Sogin, M.L., Morrison, H.G., Huber, J.A., Welch, D.M., Huse, S.M., Neal, P.R., Arrieta, J.M., Herndl, G.J., 2006. Microbial diversity in the deep sea and the underexplored "rare biosphere". Proc. Natl. Acad. Sci. U. S. A. 103 (32), 12115-12120.

Solan, M., Cardinale, B.J., Downing, A.L., Engelhardt, K.A., Ruesink, J.L., Srivastava, D.S., 2004. Extinction and ecosystem function in the marine benthos. Science 306 (5699), 1177-1180.

Spivak, A.C., Canuel, E.A., Duffy, J., Richardson, J., 2007. Top-down and bottom-up controls on sediment organic matter composition in an experimental seagrass ecosystem. Limnol. Oceanogr. 52 (6), 2595-2607.

Stachowicz, J.J., Bruno, J.F., Duffy, J.E., 2007. Understanding the effects of marine 
biodiversity on communities and ecosystems. Annu. Rev. Ecol. Evol. Syst. 38 (1), 739766.

Stahl, H., Glud, A., Schröder, C.R., Klimant, I., Tengberg, A., Glud, R.N., 2006. Timeresolved $\mathrm{pH}$ imaging in marine sediments with a luminescent planar optode. Limnol. Oceanogr. Methods 4, 336-345.

Stowasser, G., Bustamante, P., MacLeod, C.D., Wang, J., Pierce, G.J., 2005. Spawning Areas and Selected Metal Concentrations in Squid (Loligo forbesi) in UK Waters, with Notes on Metal Concentrations in Other Squid Species. Report to Geotek Ltd and Hartley Anderson Ltd in the context of the.UK Department of Trade and Industry's Offshore Energy Strategic Environmental Assessment Programme. University of Aberdeen, Aberdeen, p. 24.

Suzuki, Y. (Ed.), 1997. Marine biota and Global Carbon Cycling. University of Tokyo Press, Tokyo, p. 208.

Takano, Y., Chikaraishi, Y., Ogawa, N.O., Nomaki, H., Morono, Y., Inagaki, F., Kitazato, H., Hinrichs, K.U., Ohkouchi, N., 2010. Sedimentary membrane lipids recycled by deepsea benthic archaea. Nat. Geosci. 3, 858-861.

Tappin, A.D., Loughnane, J.P., Mc Carthy, A.J., Fitzsimons, M.F., 2012. Removal of atrazine from river waters by indigenous microorganisms. Environ. Chem. Lett. 10 (1), 89-96.

Teal, L., Parker, R., Fones, G., Solan, M., 2009. Simultaneous determination of in situ vertical transitions of color, pore-water metals, and visualization of infaunal activity in marine sediments. Limnol. Oceanogr. 54 (5), 1801-1810.

Tett, P., Gowen, R.J., Painting, S.J., Elliott, M., Forster, R., Mills, D.K., Bresnan, E., Capuzzo, E., Fernandes, T.F., Foden, J., Geider, R.J., Gilpin, L.C., Huxham, M., McQuatters-Gollop, A.L., Malcolm, S.J., Saux-Picart, S., Platt, T., Racault, M.F., Sathyendranath, S., van der Molen, J., Wilkinson, M., 2013. Framework for understanding marine ecosystem health. Mar. Ecol. Prog. Ser. 494, 1-27.

Tiedje, J.M., 1988. Ecology of denitrification and dissimilatory nitrate reduction to ammonium. Biol. Anaerob. Microorg. 717, 179-244. 
Tilman, D., 2001. Functional diversity. In: Levin, S.A. (Ed.), Encyclopedia of Biodiversity. Academic Press.

Törnroos, A., Bonsdorff, E., Bremner, J., Blomqvist, M., Josefson, A.B., Garcia, C., Warzocha, J., 2014. Marine benthic ecological functioning over decreasing taxonomic richness. J. Sea Res. (in press).

Townsend, D.W., Cammen, L.M., 1988. Potential importance of the timing of Spring plankton blooms to benthic-pelagic coupling and recruitment of juvenile demersal fishes. Biol. Oceanogr. 5 (3), 215-228.

Trites, A.W., 2003. 8 food webs in the ocean: who eats whom and how much? Responsible Fish. Mar. Ecosyst. 125.

UK National Ecosystem Assessment, 2014. The UK National Ecosystem Assessment: Synthesis of the Key Findings. UNEP-WCMC, LWEC, UK.

Ulanowicz, R.E., 2004. Quantitative methods for ecological network analysis. Comput. Biol. Chem. 28 (5), 321-339.

Valdivia, N., Molis, M., 2009. Observational evidence of a negative biodiversity-stability relationship in intertidal epibenthic communities. Aquat. Biol. 4, 263-271.

Waldbusser, G.G., Marinelli, R.L., Whitlatch, R.B., Visscher, P.T., 2004. The effects of infaunal biodiversity on biogeochemistry of coastal marine sediments. Limnol. Oceanogr. 49 (5), 1482-1492.

Wells, M.J., Clarke, M.R., 1996. Energetics: the costs of living and reproducing for an individual cephalopod. Philos. Trans. Roy. Soc. Lond. Ser. B-Biol. Sci. 351, 1083-1104.

Welsh, D.T., 2000. Nitrogen fixation in seagrass meadows: regulation, plant-bacteria interactions and significance to primary productivity. Ecol. Lett. 3, 58-71. Wheeler, P.A., North, B., Littler, M., Stephens, G., 1977. Uptake of glycine by natural phytoplankton communities. Limnol. Oceanogr. 22, 900-909.

Widdows, J., Brinsley, M., Elliott, M., 1998. Use of in Situ Flume to Quantify Particle Flux (Biodeposition Rates and Sediment Erosion) for an Intertidal Mudflat in Relation to Changes in Current Velocity and Benthic Macrofauna. In: Geological Society, London, Special Publications, vol. 139, pp. 85-97. 
Wildish, D.J., Kristmanson, D.D., 1984. Importance to mussels of the benthic boundary layer. Can. J. Fish. Aquat. Sci. 41 (11), 1618-1625.

Williams, S.L., 2001. Reduced genetic diversity in eelgrass transplantations affects both population growth and individual fitness. Ecol. Appl. 11 (5), 1472-1488.

Williams, P.I., Robertson, J.E., 1991. Overall planktonic oxygen and carbon dioxide metabolisms: the problem of reconciling observations and calculations of photosynthetic quotients. J. Plankton Res. 13 (Suppl. 1), 153-169.

Worm, B., Barbier, E.B., Beaumont, N., Duffy, J.E., Folke, C., Halpern, B.S., Jackson, J.B., Heike, K., Lotze, H.K., Micheli, F., Palumbi, S.R., Sala, E., Selkoe, K.A., Stachowicz, J.J., Watson, R., 2006. Impacts of biodiversity loss on ocean ecosystem services. Science 314, 787-790.

Wotton, R.S., Malmqvist, B., 2001. Feces in aquatic ecosystems: feeding animals transform organic matter into fecal pellets, which sink or are transported horizontally by currents; these fluxes relocate organic matter in aquatic ecosystems. BioScience 51 (7), $537-544$. 